\title{
Constructing the Yellow Brick Road: Preventing Discrimination in Financial Services Against the LGBTQ+ Community
}

Cyrus Mostaghim

American University Washington College of Law, cm7840a@student.american.edu

Follow this and additional works at: https://digitalcommons.wcl.american.edu/stu_upperlevel_papers

Part of the Banking and Finance Law Commons

\section{Recommended Citation}

Cyrus Mostaghim, Comment, Constructing the Yellow Brick Road: Preventing Discrimination in Financial Services Against the LGBTQ+ Community, 11 MICH. BUS. \& ENTREPRENEURIAL L. REV. 63 (2021).

This Article is brought to you for free and open access by the Student Works at Digital Commons @ American University Washington College of Law. It has been accepted for inclusion in Upper Level Writing Requirement Research Papers by an authorized administrator of Digital Commons @ American University Washington College of Law. For more information, please contact kclay@wcl.american.edu. 


\title{
CONSTRUCTING THE YELLOW BRICK ROAD: PREVENTING DISCRIMINATION IN FINANCIAL SERVICES AGAINST THE LGBTQ+ COMMUNITY.
}

\author{
Cyrus Mostaghim*
}

\begin{abstract}
The Lesbian, Gay, Bisexual, Transgender, Queer, and Questioning ("LGBTQ+") community lacks explicit statutory protections from discrimination in financial services. After the Supreme Court held in Bostock that employment discrimination based on sexual orientation or gender identity was illegal, the Consumer Financial Protection Bureau (CFPB) issued an informal interpretive rule for the Equal Credit Opportunity Act (ECOA) and Regulation $B$ that made discrimination in the access to credit based on sexual orientation or gender identity illegal.
\end{abstract}

However, this article argues that an informal interpretive rule is easily rescinded and does not provide sufficient protection. Thus, alternative action is needed to create ore durable protection from discrimination against the $L G B T Q+$ community in the provision of financial services. Additionally, the increased use of AI in the financial industry magnifies the need for more durable protections to prevent the accidental usage of biased data to build and train the industry's AI algorithms.

This article examines the potential and limitations of existing consumer protection laws, possible pathways to create more permanent protection, and potential impacts from regulatory changes. This article also considers additional regulatory changes to other consumer protection statutes that may be needed to enable the identification of discriminatory acts. These changes may require financial institutions to collect sexual orientation and gender identity

* Cyrus Mostaghim is a 2022 J.D. Candidate in the Evening Division of the American University Washington College of Law. I would like to thank all of my friends, family, and work colleages for their support and encouragement over the last two years as I worked on this article, in addition to the pursuit of my legal degree. Special thanks to Professor Hilary Allen for her time, mentorship, and encouragement of my research. Finally, the Michigan Business \& Entrepreneurial Law Review for their effort and help throughout the publication process.

DISCLAIMER: While the author is an employee of the Consumer Financial Protection Bureau ("CFPB"), this article's contents reflect the author's thoughts as a private citizen, not as an employee or representative of the CFPB. The author wrote this article using only publicly available information and without the misuse of any CFPB resources. The article's contents should not be interpreted to be associated with the CFPB in any manner or construed in any way to be a representation or statement from the CFPB. 
data - something that must be done with sensitivity because of a data privacy issue unique to the community: accidental outing.

\section{TABLE OF CONTENTS}

I. INTRODUCTION.

II. THE NEED FOR ENHANCED PROTECTIONS FOR THE

LGBTQ+ COMMUNITY

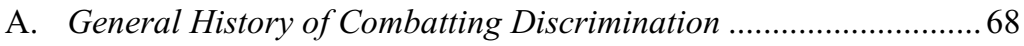

B. The LGBTQ+ Community Lacks General Concrete

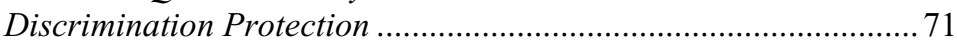

C. The LGBTQ+ Community's Current Protections for Access to Financial Services.

D. CFPB's Role in Consumer Finance ...............................................78

III. Potential Changes to Fair Lending Statutes OR

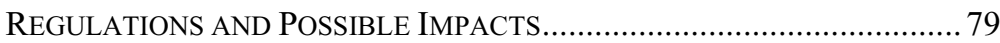

A. The Community Reinvestment Act of 1977 (CRA) ............................ 79

B. The Equal Credit Opportunity Act (ECOA) ..................................... 81

C. The Home Mortgage Disclosure Act (HMDA) ................................ 83

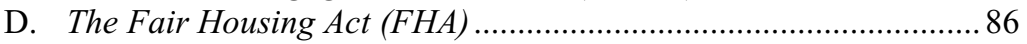

E. The Fair Credit Reporting Act (FCRA) …………........................ 87

F. The Fair Debt Collection Practices Act (FDCPA) ..........................8 88

G. Unfair, Deceptive Acts and Practices (UDAP) and Unfair, Deceptive or Abusive Acts and Practices (UDAAP) _......................... 89

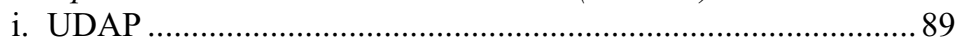

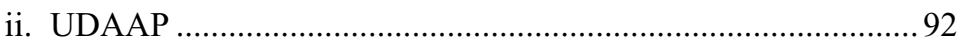

H. State-Level Laws and Regulations Serving as a Resource

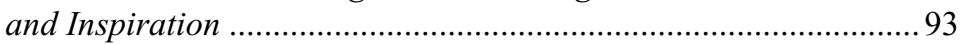

IV. WAYS ThAT MORE CONCRETE PROTECTION CAN BE CREATED ............ 93

A. Why More Concrete Protection is Needed.......................................93

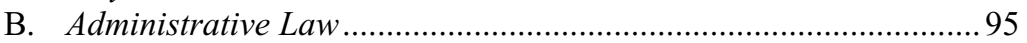

C. Classifying the LGBTQ+ Community as a Quasi-Suspect Class....98

D. Congressional Action and New Legislation .....................................102

E. The Equality Amendment to the Constitution .................................102

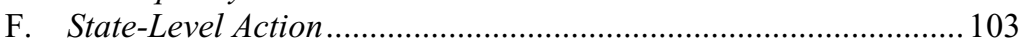

V. Potential IMPaCtS OF REgUlatoRy CHANGES ................................. 104

A. Costs of Complying with New Regulatory Changes ....................... 104

B. Increased Complexity in Supervision, Enforcement, and

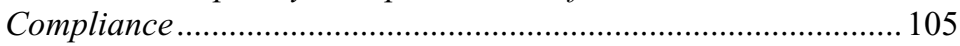

C. Implications Related to Data Privacy Statutes ............................... 106

VI. MOVING TO THE FUTURE: FAIR LENDING AND FINTECH'S USE OF MACHINE LEARNING AIS .................................................................... 108

A. Machine Learning AI's Role in Fintech and the Potential Liabilities....

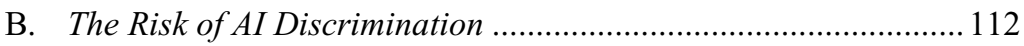

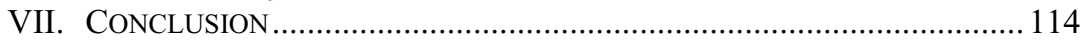




\section{INTRODUCTION}

Picture it, going to the bank to apply for a mortgage loan and the employee refusing to give you an application because of whom you love or how you are dressed.

In 1998, L. ${ }^{1}$ Rosa, a transgender woman, encountered discrimination when she tried to obtain a mortgage application. ${ }^{2}$ At the bank, an employee refused to provide an application because the clothing Rosa wore did not conform with the birth gender that was listed on her identification. ${ }^{3}$ Or imagine how Adola DeWolf and Laura Watts, a lesbian couple, felt as they faced the threat of foreclosure when they tried to update mortgage documents to recognize their partnership because the bank did not recognize domestic partnerships. ${ }^{4}$

Homeownership is an integral part of the "Great American Dream." However, for the Lesbian, Gay, Bisexual, Transgender, and Queer (LGBTQ+) community (or "the community"), achieving homeownership is much more difficult than for their heterosexual peers, in part because of the hurdles they face when accessing financial services. ${ }^{5}$ While there are few federal cases related to financial discrimination against the LGBTQ+ community, discrimination against the community persists and creates hurdles when accessing the financial services needed to buy a home. ${ }^{6}$ Discrimination in financial services occurs when a negative action, such as denial of credit or a higher interest rate, is based on a protected status, like race, gender, or receiving federal assistance, or when an action has a disparate impact on a protected class. ${ }^{7}$ Several recent studies have asserted the existence of discrimination against the community via analysis of Home Mortgage Disclosure Act (HMDA) data of same-sex applicants as a proxy

1. Author's note: The legal first name in the court records for Ms. Rosa is Lucas. However, out of respect and uncertainty based on records that are more than twenty years old, I am only using the first initial in this article's text to avoid potentially using Ms. Rosa's deadname (name given at birth that typically only aligns with the individual's birth gender).

2. Rosa v. Park W. Bank \& Tr. Co., 214 F.3d 213, 214 (1st Cir. 2000).

3. Id.

4. DeWolf \& Watts v. Countrywide, LAMBDA LEGAL, [hereinafter DeWolf \& Watts Summary], https://www.lambdalegal.org/in-court/cases/dewolf-and-watts-v-countrywide (last visited Apr. 17, 2021) (summarizing claim from unreported case that resulted in settlement).

5. See Adam P. Romero et Al., LGBT People and Housing Affordability, DisCRIMINATION, AND HOMELESSNESS 3, 10-12, 14 (UCLA Sch. L. Williams Inst. Ed., 2020), https:// williamsinstitute.law.ucla.edu/wp-content/uploads/LGBT-Housing-Apr-2020.pdf (covering various statistics of LGBTQ+ housing affordability, homeownership rates, and homelessness rates); Homeownership: The American Dream, HUD User: OfFice of POLICY Development AND RESEARCH (Aug. 13, 2018), https://www.huduser.gov/portal/pdredge/pdr-edge-frm-asst-sec081318.html.

6. See id.

7. See 12 U.S.C $\S 2901$ (requiring financial institutions to "serve the convenience and needs of the communities in which they are chartered to do business"); Equal Credit Opportunity Act (ECOA), 15 U.S.C. $§ 1691$ (defining credit decision discrimination); e.g., Comcast Corp. v. Nat'1 Ass'n of African-American Owned Media, 140 S. Ct. 1009 (2020) (claiming declined business relationship based on plaintiff's race was discrimination). 
for LGBTQ+ applicants. ${ }^{8}$ One study found that for non-objective reasons, samesex applicants were charged between $0.02 \%-0.20 \%$ more interest than similarly situated opposite-sex applicants. ${ }^{9}$ While there are already some legal protections against this type of discrimination, this article argues that they are insufficient and that more concrete protections are needed.

Many of the fair lending laws and regulations, and federal anti-discrimination laws and regulations in general, define protected classes using the same categories as Title VII of the Civil Rights Act of 1964 (as interpreted by the Equal Employment Opportunity Commission (EEOC)). ${ }^{10}$ The EEOC is the federal agency responsible for enforcing federal laws that deal with employment discrimination, including Title VII. ${ }^{11}$ Before the decision in Bostock v. Clayton County, ${ }^{12}$ agencies had the choice whether or not to defer to the EEOC's interpretation that discrimination based on sexual orientation or gender identity was a type of sex discrimination. ${ }^{13}$ While the Bostock decision codified the EEOC's interpretation into law, the interpretation only applies to Title VII, and

8. See e.g., J. Shahar Dillbary \& Griffin Edwards, An Empirical Analysis of Sexual Orientation Discrimination, 86 U. CHI. L. REV. 1, 4 (2019) (using HMDA data to identify trends in discriminatory lending against LGBTQ+ community); Hua Sun \& Lei Gao, Lending Practices to Same-Sex Borrowers, 116 PROC. NAT'L. ACAD. SCI. 9293, 9293 (2019) (discussing trends in discrimination against same-sex applicants with spillover effects to opposite-sex applicants, an indicator of reverse redlining), https://www.pnas.org/content/116/19/9293; Jason Richardson \& Karen Kali, Same-Sex Couples and Mortgage Lending, NaT'L CMTY ReInV. CoAl (2020), https://ncrc.org/same-sex-couples-and-mortgage-lending/ (last accessed Sept. 19, 2020) (finding indicators of discrimination against same-sex couples); Anneliese Lederer \& Jake Lilien, Lending Discrimination Faced by Same-Sex Couples in the Mortgage Arena, NAT'L CMTY. REINVESTMENT COAL. (2020), https://ncrc.org/lending-discrimination-faced-by-same-sex-couples-in-the-mortgagearena/ (discussing findings from the NCRC report by Richardson and Kali).

9. Sun \& Gao, supra note 8.

10. Title VII, 42 U.S.C. $§ 2000 \mathrm{e}-2$ (prohibiting employment discrimination based on race, color, religion, sex, or national origin); see Equal Credit Opportunity Act (ECOA), 15 U.S.C. § 1691 (prohibiting discrimination in providing credit based on race, color, religion, national origin, sex or marital status, or age); Fair Housing Act (FHA), 42 U.S.C. $\S \S 3601-31$ (prohibiting discrimination based on race, color, national origin, religion, sex, familial status, or handicap status for certain housing-based actions).

11. EEOC, Overview, U.S. EQUAL EMPLOYMENT OPPORTUNITY COMMISSION, https://www.eeoc.gov/overview (last visited Apr. 29, 2021).

12. 140 S. Ct. 1731 (2020).

13. Title VII, 42 U.S.C. $\S 2000 \mathrm{e}-2$; Sex-Based Discrimination, EEOC, [hereinafter EEOC Discrimination Guidance], https://www.eeoc.gov/laws/types/sex.cfm (last visited Nov. 7, 2019) (stating sexual orientation and gender identity are sex discrimination under Title VII); Memorandum from Eric Holder, Att'y Gen., DOJ, to U.S. Attorneys and Heads of Department Components (Dec. 15, 2014) [hereinafter Holder Memo], https://www.justice.gov/file/188671/download (stating DOJ will interpret transgender employment discrimination as sex discrimination under Title VII); Letter from Richard Cordray, Director, CFPB, to Michael Adams, CEO, Services \& Advocacy for GLBT Elders (SAGE) (Aug. 30, 2016) [hereinafter CFPB SAGE Letter], https://www.cfpbmonitor.com/wpcontent/uploads/sites/5/2016/09/SAGE-Letter.pdf (stating CFPB's interprets ECOA covers sexual orientation and gender identity as sex discrimination and citing EEOC's Title VII interpretation); Memorandum from Jeff Sessions, Att'y Gen., DOJ, to U.S. Attorneys and Heads of Department Components (Oct. 4, 2017) [hereinafter Sessions Memo], https://assets.documentcloud.org /documents/4067383/Attachment-2.pdf (reversing Holder's interpretation for DOJ). 
federal financial regulators can still choose whether or not to follow the EEOC in recognizing discrimination based on sexual orientation or gender identity. ${ }^{14}$ However, Bostock can and has been used as justification to adopt a similar interpretation in other areas of law that deal with sex-based discrimination. ${ }^{15}$

On January 20, 2021, President Biden issued Executive Order (EO) 13,988 that established an overarching position on policy to combat any discrimination based on sexual orientation or gender identity. ${ }^{16}$ The order directs all federal agencies to review all "existing orders, regulations, guidance documents, policies, programs or other agency actions that" are related to sex-based discrimination and take any necessary action to prevent discrimination based on sexual orientation or gender identity. ${ }^{17}$ In March of 2021, the Consumer Financial Protection Bureau (CFPB) released an informal interpretive rule regarding the Equal Credit Opportunity Act (ECOA) and Regulation B that addressed discrimination based on sexual orientation or gender identity. ${ }^{18}$ The interpretive rule states that in the eyes of CFPB, discrimination based on sexual orientation or gender identity is a form of sex-based discrimination and is illegal under ECOA and Regulation B. ${ }^{19}$

While EO 13,988 and CFPB's interpretive rule are welcome progress, there are serious weaknesses with the creation of protections in this manner. EOs are easily and commonly revoked after a change in party for a presidential

14. Bostock, 140 S. Ct. at 1737 .

15. Sharita Gruberg, Beyond Bostock: The future of LGBTQ Civil Rights, CTR. FOR AM. PROGRESS, https://www.americanprogress.org/issues/lgbtq-rights/reports/2020/08/26/489772/beyondbostock-future-lgbtq-civil-rights/ (postulating the application and impact of Bostock in employment, education, health care, and housing); Katie Keith, Another Court Vacates LGBTQ-Specific Rollbacks from New 1557 Rule, HeAlth AFFs. (Sept. 4, 2020), https://www.healthaffairs.org/do/10.1377 /hblog20200904.528322/full/ (discussing impact of Bostock on HHS rule to roll back healthcare protections for the LGBTQ+ community); Cyrus Mostaghim, Coming Out of the Title VII Closet: Bostock's Potential Ripple Effects on Financial Regulation, AM. U. BUS. L. ReV.: THE BLR BuZZ BLOG (Sept. 27, 2020) [hereinafter Mostaghim, Bostock's Ripple Effects], http://www.aublr.org/2020 /09/coming-out-of-the-title-vii-closet-bostocks-potential-ripple-effects-on-financial-regulation/ (serving as author's initial analysis of CFPB's RFI on potentially using the holding from the Bostock case to update ECOA to cover sexual orientation and gender identity and providing additional background information).

16. Exec. Order No. 13,988, 86 Fed. Reg. 7,023 (Jan. 20, 2021) [hereinafter EO 13,988].

17. Id. at $7023-24$.

18. Equal Credit Opportunity (Regulation B); Discrimination on the Bases of Sexual Orientation and Gender Identity, 86 Fed. Reg. 14363 (Mar. 16, 2021) (to be codified at 12 C.F.R. pt. 1002); CFPB Clarifies That Discrimination on the Basis of Sexual Orientation and Gender Identity is Illegal, CONSUMER FIN. PROTECTION BUREAU (Mar. 09, 2020) [hereinafter CFPB ECOA Announcement], https://www.consumerfinance.gov/aboutus/newsroom/cfpb-clarifies-discrimination-by-lenders-on-basis-of-sexual-orientation-and-gender-identity-isillegal/.

19. Equal Credit Opportunity (Regulation B); Discrimination on the Bases of Sexual Orientation and Gender Identity, 86 Fed. Reg. 14363 (Mar. 16, 2021) (to be codified at 12 C.F.R. pt. 1002); CFPB ECOA Announcement, supra note 18. 
administration. ${ }^{20}$ With regard to CFPB's informal interpretive rule, these kinds of rules are easily rescinded and face additional hurdles when used for the basis of an enforcement action. ${ }^{21}$ Thus, further action is needed via regulatory, legislative, or judicial action (or a combination of the three) to create concrete protection for the LGBTQ+ community. ${ }^{22}$ Such action must be particularly sensitive to the unique privacy concerns that members of the LGBTQ+ community may have with regard to accidental "outing," which complicates data collection for regulatory oversight. ${ }^{23}$ Finally, the use of artificial intelligence (AI) machine learning algorithms (specifically neural nets) and the fintech industry's rapid growth makes it imperative that action is taken as soon as possible. Every day that passes allows these AIs to learn from and use potentially discriminatory data, thereby building discrimination into the foundation of AIs and our finance industry. ${ }^{24}$

This article demonstrates the need for a more concrete and permanent legal response to financial discrimination against the LGBTQ+ community as follows: Part II provides some background on the history of discrimination and the legal responses to it, while Part III discusses the various consumer finance statutes and the roles that they could play in preventing financial discrimination against the LGBTQ+ community. Part IV discusses the possible paths to creating more concrete legal protection, and Part V discusses some of the potential impacts if regulatory changes are pursued. Part VI will discuss the importance of preventing discrimination from being built into the financial system via AI algorithms trained with discriminatory data. Finally, Part VII will conclude.

\section{THE NEED FOR ENHANCED PROTECTIONS FOR THE LGBTQ+ COMMUNITY}

\section{A. General History of Combatting Discrimination}

The Supreme Court has identified certain minority groups that require heightened scrutiny to protect them. ${ }^{25}$ The process for identifying a "quasisuspect class" began with the definition in footnote four of United States v. Carolene Products Company. ${ }^{26}$ In the footnote, the Supreme Court stated that it would take a closer look at cases that involved laws that affected "discrete and insular minorities," also referred to as quasi-suspect classes in the Court's case

20. What is an Executive Order?, ABA: TEACHING LEGAL Docs (Jan. 25, 2021), https://www.americanbar.org/groups/public_education/publications/teaching-legal-docs/what-is-anexecutive-order-l.

21. See infra Part IV Section b.

22. See infra Part IV Section b.

23. See infra Parts V Section c, VI.

24. See infra Part VI.

25. See United States v. Carolene Prods. Co., 304 U.S. 144, 153 n.4 (1938) (discussing discrete and insular minorities)

26. See id. 
history. ${ }^{27}$ In subsequent cases, the Court articulated the factors used to determine if a group could qualify as a quasi-suspect class. ${ }^{28}$ The case of City of Cleburne v. Cleburne Living Center, Inc. ${ }^{29}$ expressed these factors (the "Cleburne factors") most clearly: (1) the history of discrimination to see how deep-seated it was and how long it lasted, (2) the group's access to political power and ability to affect change to it, and (3) whether the group is a minority with immutable characteristics and keeps to itself. ${ }^{30}$

In addition to establishing when a group is a quasi-suspect class, the Supreme Court precedent has also determined the levels of scrutiny that all courts must use to review challenges to laws that dictate the treatment of a quasi-suspect class. ${ }^{31}$ There are three levels of scrutiny, rational, intermediate, and strict. ${ }^{32}$ Rational basis is the default level of scrutiny used for non-quasi-suspect classes, and "a law will be upheld if it is rationally related to a legitimate government purpose." 33 The burden of proof for rational basis falls with the challenger. ${ }^{34}$ For "intermediate scrutiny, a law is upheld if it is substantially related to an important government purpose... [and] the government has the burden of proof." 35 The reason must have a "substantial relationship" to the desired outcome. ${ }^{36}$ For strict scrutiny, the government has the burden of proof and must convince the court that a compelling purpose for the law exists, the law is narrowly tailored to achieve the purpose, and a less discriminatory alternative does not exist. ${ }^{37}$

27. Id.

28. See e.g., City of Cleburne, Tex. v. Cleburne Living Ctr., Inc., 473 U.S. 432, 438 (1985) (discussing Fifth Circuit's analysis to determine intellectual disability was a quasi-suspect classes).

29. Id.

30. Id. at 438 .

31. See ERWin ChEMERINSKy, Constitutional Law 725-948 (Rachel E. Barkow et al. eds., 5th ed. 2017) (providing information on levels of scrutiny, how they are used, the level applied to recognized quasi-suspect classes, and abridged versions of cases involving quasi-suspect classes).

32. Id. at 728 .

33. Id.

34. Id. at 727-28.

35. Id.

36. $I d$.

37. Id. at 727 . 
African Americans were the first group recognized as a quasi-suspect class. ${ }^{38}$ The major milestones were the holding in Brown v. Board of Education, ${ }^{39}$ that segregation in education based on race was unconstitutional, the passage of the Civil Rights Act of 1957, and the holding in Loving v. Virginia,${ }^{40}$ that marriage restriction based on race was unconstitutional. ${ }^{41}$ Quasi-suspect status was eventually expanded to include all racial minorities. ${ }^{42}$

Women have also suffered discrimination: the original Constitution's text did not recognize women's rights and women had no right to vote until the Nineteenth Amendment was adopted in $1920 .{ }^{43}$ Making progress on women's rights took time and often required demonstrating that discrimination based on sex also harmed men, like in Moritz v. Commissioner, ${ }^{44}$ where the court found that the IRS had discriminated against a man by disallowing a tax deduction that it would have allowed for a woman. ${ }^{45}$ In 1989, in Price Waterhouse v. Hopkins, ${ }^{46}$ the court found that discrimination based on sex stereotypes was a form of sex discrimination. ${ }^{47}$

Although the LGBTQ+ community has faced some form of persecution since before the founding of this country, the Supreme Court's recognition of the civil

38. See U.S. CONST. art. I, $\S 2$, cl. 3 (establishing representation based on the number of free persons and the three fifths rule, while excluding Native Americans); $i d$. amends. XIII-XV (abolishing slavery, creating equal representation and protection, and prohibiting discrimination based on race); Title VII, 42 U.S.C. $§ 2000 \mathrm{e}-2$ (prohibiting employment discrimination based on race, color, religion, sex, or national origin); Loving v. Virginia, 388 U.S. 1, 12 (1967) (holding that race-based restrictions on marriage are unconstitutional); Brown v. Bd. of Educ. of Topeka, Kan., 347 U.S. 483, 495-96 (1954) (finding "separate but equal" unconstitutional for public education), enforced, Brown v. Bd. of Educ. of Topeka, Kan., 349 U.S. 294 (1955) (finding compliance with court's 1954 decision required public schools to desegregate); Plessy v. Ferguson, 163 U.S. 537, 551-52 (1896) (finding separate but equal segregation based on race constitutional), overruled by Brown, 347 U.S. 483 (1954); infra footnotes 43-47 and associated text.

39. 347 U.S. 483, 495-96 (1954), enforced, 349 U.S. 294 (1955).

40. 388 U.S. 1 (1967)

41. The Civil Rights Act of 1957, Pub. L. No. 85-315, 71 Stat. 634 (1957); Loving, 388 U.S. 1, 12 (1967); Brown, 349 U.S. 294, 294 (1955).

42. The Civil Rights Act of 1957, Pub. L. No. 85-315, 71 Stat. 634 (1957) (creating commission to study denial of voting rights based on race and other classifications); see Korematsu v. United States, 323 U.S. 214 (1944) (applying strict scrutiny because the order targeted people of Japanese descent), abrogated by Trump v. Hawaii, 138 S. Ct. 2392 (2018).

43. U.S. CONST. amend. XIX; see generally U.S. CONST. (not mentioning women).

44. 469 F.2d 466 (10th Cir. 1972).

45. Id. at 470 .

46. 490 U.S. 228 (1989).

47. Id. at 251; see also Hearing on Financial Services and the LGBTQ+ Community: A Review of Discrimination in Lending and Housing Before the H. Comm on Fin. Serv., 116th Cong. 10-15 (2019) (statement of Harper Jean Tobin, Director of Policy, National Center for Transgender Equality) [hereinafter Tobin] (discussing federal case law on sex-based stereotypes and HUD's acknowledgement of applicability to the Fair Housing Act and associated administrative rules). 
rights of the LGBTQ+ community has been relatively rapid when compared with its progress on the rights of women and racial minorities. ${ }^{48}$

\section{B. The LGBTQ+ Community Lacks General Concrete Discrimination Protection}

This timeline started with the initial losses in Baker v. Nelson, ${ }^{49}$ the first case that argued the constitutionality of gay marriage in 1972, and Bowers $v$. Hardwick, ${ }^{50}$ a 1986 case where the Court held that LGBTQ+ individuals did not have a right to sexual privacy. ${ }^{51}$ However, ten years after Bowers, the tides began to shift in favor of the community in Romer v. Evans, ${ }^{52}$ where the Court found that a state constitutional amendment barring and undoing local LGBTQ+ antidiscrimination laws was unconstitutional. ${ }^{53}$ In the 2003 decision Lawrence $v$. Texas, ${ }^{54}$ the Court found that the community had a right to sexual privacy. ${ }^{55}$ Over the next seventeen years, the community gained the right to marry via Obergefell v. Hodges, ${ }^{56}$ and protection from discrimination in employment via Bostock. ${ }^{57}$ Outside the contours of these specific court decisions, though, the LGBTQ+ community's legal protections exist in a gray area. ${ }^{58}$ Sexual orientation and

48. See GSAFE, A Timeline of Lesbian, Gay, Bisexual, and Transgender History in the United States, [hereinafter GSAFE LGBTQ+ Timeline] https://www.gsafewi.org/wp-content/uploads/USLGBT-Timeline-UPDATED.pdf (last visited Apr. 29, 2021) (providing timeline of LGBTQ+ legal issues in United States); Milestones in the American Gay Rights Movement, PBS, [hereinafter PBS $L G B T Q+$ Timeline] https://www.pbs.org/wgbh/americanexperience/features/stonewall-milestonesamerican-gay-rights-movement/ (last visited July, 17 2021) (describing important events and figures in gay rights timeline); LGBTQ Rights Timeline in American History, FAIR ED. ACT IMPLEMENTATION COAL., [hereinafter Fair Educ. LGBTQ+ Timeline] https://www.lgbtqhistory.org /lgbt-rights-timeline-in-american-history/ (last visited July 17, 2021) (providing timeline of gay rights in U.S. history and mentioning important figures). See also sources cited supra note 38; Obergefell v. Hodges, 576 U.S. 644, 681 (2015) (establishing LGBTQ+ community's marriage rights); Bowers v. Hardwick, 478 U.S. 186, 196 (1986) (finding no sexual privacy right for LGBTQ+ community), overruled by Lawrence v. Texas, 539 U.S. 558 (2003); Baker v. Nelson, 409 U.S. 810, 810 (1972) (dismissing appeal for want of federal question regarding right to gay marriage), overruled by Obergefell v. Hodges, 576 U.S. 644 (2015).

49. 409 U.S. 810 (1972), overruled by Obergefell, 576 U.S. 644 (2015).

50. 478 U.S. $186(1986)$.

51. Baker, 409 U.S.; Bowers, 478 U.S. at 196 (1986).

52. 517 U.S. 620 (1996).

53. Romer v. Evans, 517 U.S. 620, 635-36 (1996).

54. 539 U.S. 558 (2003).

55. Lawrence v. Texas, 539 U.S. 558, 578-79 (2003).

56. 576 U.S. 644 (2015).

57. Bostock v. Clayton Cnty., 140 S. Ct. 1731, 1754 (2020); Obergefell, 576 U.S. 644, 681 (2015).

58. See generally Tobin supra note 47, at 10-15 (discussing history of HUD's Equal Access Rule and Secretary Carson's actions to undo previous LGBTQ+ related protections). See cases cited supra note 48; United States v. Windsor, 570 U.S. 744, $774-75$ (2013) (finding Defense of Marriage Act's restrictions on LGBTQ+ community unconstitutional without stating level of scrutiny used); 
gender identity are not explicitly listed as a protected status in the language of any federal statute, and the Supreme Court has never explicitly stated the level of scrutiny that should be applied to assess laws that discriminate against the community. ${ }^{59}$

Before the Supreme Court's decision in Bostock, sexual orientation and gender identity had been somewhat protected in employment contexts. ${ }^{60}$ The EEOC had interpreted Title VII such that employment discrimination based on sexual orientation and gender identity was a form of sex discrimination. ${ }^{61}$ This interpretation gave sexual orientation and gender identity protections under the "sex stereotypes" definition from the Supreme Court's decision in Price Waterhouse. ${ }^{62}$ Under the EEOC's interpretation, discrimination against an LGBTQ+ individual because of the stereotype that men should be married to women, and vice versa, is discrimination based on sex. ${ }^{63}$ However, while the Bostock decision confirmed the EEOC's interpretation and gave it the full force of the law, the protection only applies to employment discrimination under Title VII. ${ }^{64}$ Other federal regulators can choose to follow or ignore the EEOC's interpretation. ${ }^{65}$ Thus, the LGBTQ+ community faces uncertainty regarding their legal protections outside of the employment context. ${ }^{66}$

\section{The LGBTQ+ Community's Current Protections for Access to Financial Services.}

A 2020 study by the UCLA School of Law's Williams Institute revealed that in the U.S., $21.6 \%$ of LGBTQ+ adults live in poverty as opposed to $15.7 \%$ of their cis-gendered heterosexual adult counterparts. ${ }^{67}$ The same study found that

Romer, 517 U.S. 620, 635-36 (1996) (finding unconstitutional state constitution amendment barring and undoing local LGBTQ+ antidiscrimination laws using rational basis without stating use).

59. See cases cited supra note 48. See generally Home Mortgage and Disclosure Act (HMDA) of 1975, 12 U.S.C. § 2801; Community Reinvestment Act (CRA), 12 U.S.C § 2901; Equal Credit Opportunity Act (ECOA), 15 U.S.C. § 1691.

60. See Tobin, supra note 47 at 8; EEOC Discrimination Guidance, supra note 13.

61. See Tobin, supra note 47 at 8 (EEOC "clarifying that claims of discrimination based on transgender status, also referred to as claims of discrimination based on gender identity, are cognizable under Title VII's sex discrimination prohibition."); EEOC Discrimination Guidance, supra note 13.

62. 490 U.S., 228, 251 (1989) (finding discrimination based on sex stereotypes is sex discrimination).

63. EEOC Discrimination Guidance, supra note 13

64. Bostock, 140 S. Ct. at 1737.

65. See Tobin, supra note 47 at 14-15 (discussing HUD's adoption and subsequent attempt to reverse the Equal Access Rule "designed to protect LGBTQ+ people experiencing homelessness."). See also Holder Memo, supra note 13; CFPB SAGE Letter, supra note 13; EEOC Discrimination Guidance, supra note 13 (stating Title VII only addresses discrimination in employment practices); Sessions Memo, supra note 13.

66. See generally Tobin, supra note 47 at 14-15; EEOC Discrimination Guidance, supra note 13; CFPB SAGE Letter, supra note 13.

67. See Romero ET AL., supra note 5, at 10 (covering various statistics of LGBTQ+ housing affordability, homeownership rates, and homelessness rates). 
$49.8 \%$ of LGBTQ+ adults own a home compared to $70.1 \%$ of non-LGBTQ+ adults, between $20-45 \%$ of homeless youth are LGBTQ+, and LGBTQ+ adults "aged $18-25, \ldots$ have a 2.2 times greater risk of homelessness than nonLGBT $\left[\mathrm{Q}^{+}\right]$people." ${ }^{68}$ These statistics run counter to the stereotype that LGBTQ+ Americans are part of a wealthy demographic, commonly referred to as Single/Dual Income No Kids. ${ }^{69}$ For the more vulnerable members of the LGBTQ+ community, access to financial services can be critical in obtaining housing. ${ }^{70}$

There is a long history of discrimination in the provision of financial services in the U.S., particularly discrimination against racial minorities. ${ }^{71}$ At one point, the solution was thought to be community banks catering to one or more minority groups. ${ }^{72}$ One takeaway from the African American community bank history is that a community bank avoids discrimination and better facilitates the generation of community wealth and success to support the existence of successful individuals in the community. ${ }^{73}$ Thus, some might recommend a similar community banking solution for the LGBTQ + community (something a few groups have pursued).$^{74}$ Of course, the parallels between these communities only go so far. Unlike racial minorities, much of the LGBTQ+ community has a chance of avoiding detection and discrimination by staying in the closet while trying to access financial services. ${ }^{75}$ Strategies include not disclosing their sexual orientation, applying as individuals instead of as a couple, and modifying their appearance to conform with traditional gender stereotypes. ${ }^{76}$ However, these

68. Id. at $3,11-12$.

69. Nathan McDermott, The Myth of Gay Affluence, THE ATLANTIC (Mar. 21, 2014), https://www.theatlantic.com/business/archive/2014/03/the-myth-of-gay-affluence/284570/; Julia Kagan, Dual Income No Kids, INVESTOPEDIA (June 23, 2021), https://www.investopedia.com/terms /d/dinks.asp (last visited Apr. 17, 2021); see ROMERO ET AL., supra note 67. See generally LGBTQ+ Real Est. All, The Inaugural Housing Policy Symposium RePort From the LGBTQ+ REAL Estate Alliance 22, 27 (2021) [hereinafter LGBTQ+ Housing REPORT], https:// realestatealliance.org/wp-content/uploads/2021/05/alliance_v2-1.pdf (discussing LGBTQ+ housing statistics).

70. See LGBTQ+ HOUSING REPORT, supra note 69, at 27 (discussing transgender housing discrimination).

71. MEHRSA BARADARAN, THE COLOR OF MONEY 1, 5, 12 (2017) (discussing discrimination against African Americans and other racial minorities in banking and access to credit).

72. See id. at 5 (analyzing difference in success of community banks for different minority groups). See also id. at 46 (discussing how Jim Crow necessitated creation of African American banks).

73. See id. at 42 (stating that reason for creation of some African American community affiliated banks was to serve the community's needs so loan decisions were often based on community impact instead of traditional underwriting principles).

74. See infra notes 77-84 and accompanying text.

75. See Jack Drescher, The Closet: Psychological Issues of Being In and Coming Out, PSYCHIATRIC TIMES (Oct. 1, 2004), https://www.psychiatrictimes.com/view/closet-psychologicalissues-being-and-coming-out (discussing how LGBTQ+ individuals stay in the closet).

76. See id.; LGBTQ+ HOUSING REPORT, supra note 69, at 23 (surveying LGBTQ+ individuals with $13.8 \%$ admitting to signing forms "that did not adequately represent their life experience"). 
approaches are not always desirable or viable, especially for the transgender community, so there may be a place for community banking as a solution to some of these more unique challenges.

In 2019, the state of Michigan approved the charter for Superbia Credit Union; the first LGBTQ+-focused national financial institution. ${ }^{77}$ Michael Myers, Superbia's founder, was inspired to counteract certain issues that plagued members of the LGBTQ+ community. ${ }^{78} \mathrm{He}$ cited issues including denying phone services to a transgender account holder for not sounding like the gender on file and denying mortgage services to a qualified same-sex couple shortly after gay marriage was legalized in 2015. ${ }^{79}$ However, Superbia is not the first or only LGBTQ+ community-based financial institution. ${ }^{80}$

The first LGBTQ+ community-based financial institution appears to be the Dallas Gay Alliance Credit Union (DGACU), a state-chartered institution created in $1988 .{ }^{81}$ The DGACU had a short lifespan of less than ten years before it was

77. See Ruth Umoh, America's First LGBT-Focused Credit Union to Launch in 2020, FORBES (Sept. 16, 2019), https://www.forbes.com/sites/ruthumoh/2019/09/16/americas-first-lgbt-focusedcredit-union-to-launch-in-2020/\#7fa48b315d17.

78. Karma Allen, Meet the Man Hoping to Battle LGBTQ Bank Discrimination with a New Credit Union, ABC News (Oct. 9, 2019), [hereinafter Karma Allen] https://abcnews.go.com/US /meet-man-hoping-battle-lgbtq-bank-discrimination-credit/story?id=65947300.

79. Id. See generally Mission, SUPERBIA, https://superbia.org/mission/ (last visited Apr. 18. 2021) (stating Superbia's mission "to provide discrimination-free banking, life and health insurance, and money management services designed for and by the LGBTQ community").

80. See Press Release, Dallas Gay Alliance, Dallas Gay Alliance Forms Credit Union (Nov. 9, 1988) [hereinafter Dallas LGBTQ+ CU] https://texashistory.unt.edu/ark:/67531/metadc804590/ (announcing creation of state-chartered LGBTQ+ credit union in Dallas, TX in 1988); David Taffet, Queer Banking, DALlAS VoICE (Apr. 30, 2021), https://dallasvoice.com/queer-banking/ (discussing Dallas credit union and creation of Daylight bank, the first digital bank for LGBTQ+ community); Alexandria White, Daylight Launches as the First LGBTQ+ Digital Banking Platform, CNBC (Nov.

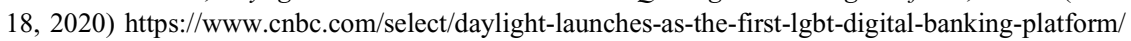
(highlighting creation of Daylight digital banking platform and services offered); Who We Are, DAYLIGHT, https://joindaylight.com/who-we-are (last visited June 13, 2021) (providing background information on Daylight bank and its mission); Peter Strozniak, Two LGBTQ CUs in the Works, CREDIT UNION TiMES (Nov. 30, 2018, 9:00 AM), https://www.cutimes.com/2018/11/30/two-lgbtqcus-in-the-works/?slreturn=20210513190435 (highlighting creation of Superbia, a San Francisco group's plan to file for charter with NCUA to hopefully open "LGBTQ $\left.{ }^{+}\right]$Federal Credit Union by 2023[,]" and history of Dallas credit union); Matt Baume, You Can Now Put Your Gay Money in a Gay Bank, OuT (Sept. 11, 2019), https://www.out.com/news/2019/9/11/you-can-now-put-your-gaymoney-gay-bank (spotlighting creation of Superbia, attempt to create LGBTQ+ Credit Union in Washington State, and crediting Dallas Gay Alliance Credit Union as first LGBTQ+ financial institution); Michelle MacKinnon, 'This is the Time' - Group Raising Funds to Form LGBTQ+ Credit Union, CaPitol Hill SeAtTle Blog (Feb. 15, 2018), https://www.capitolhillseattle.com /2018/02/this-is-the-time-group-raising-funds-to-form-lgbtq-credit-union/ (describing efforts to create Washington state-chartered LGBTQ+ credit union and providing entity's web address: http://www.equalitywashington.org/); Equality Washington, The Campaign for Equality Credit Union, INDIEGOGO, https://www.indiegogo.com/projects/the-campaign-for-equality-credit-union/x /2119395\#/ (last visited June 13, 2021) (fundraising for Equality Credit Union and describing the institution's goals for serving the LGBTQ+ community).

81. See Dallas LGBTQ+ CU, supra note 80; Taffet, supra note 80; Strozniak, supra note 80; Baume, supra note 80. 
absorbed into another entity. ${ }^{82}$ In addition to Superbia, there have been attempts to create LGBTQ+ community-based institutions in San Francisco, Seattle, and even a digital-only institution (Daylight). ${ }^{83}$ Some of these attempts, such as the Seattle institution, have failed, while others are still at various points in the startup stage (currently underway in the chartering process or a charter has been approved and the institutions are currently building infrastructure). ${ }^{84}$

Many community-based financial institutions will face significant regulatory and operational obstacles to success. ${ }^{85}$ Discussing all the various hurdles involved with starting an LGBTQ+ community-based financial institution is beyond the scope of this article, but there are some issues that are particularly relevant to the LGBTQ+ community. The first issue relates to whether to charter as a commercial bank or a credit union. Credit unions have been the more popular institutional form due to credit unions having lower barriers to entry (regulatory hurdles and capital requirements) than banks. ${ }^{86}$ Unlike a bank, credit unions can be chartered in a basic form (offering only checking and savings accounts) or fullservice (offering loans, check cashing, and retirement accounts), each with its own unique chartering requirements. ${ }^{87}$ Basic credit unions can convert to a fullservice credit union, allowing credit unions startups to capitalize on the easier requirements (regulatory and capital) of the basic form and then converting to the full-service form when it is strategically viable for the institution. ${ }^{88}$ However, a startup bank must meet the higher regulatory and capital requirements to be chartered, giving the credit union form an advantage over a commercial bank form in the startup phase. ${ }^{89}$

Outside of the startup requirements, commercial banks do have an advantage over credit unions because they can raise the required startup capital by issuing shares of stock to investors who are willing to provide capital with the expectation that they will receive a return on investment via dividends from profits. ${ }^{90}$ Unlike a bank, a credit union cannot sell shares of stock to the general public because of

82. See sources cited supra note 81 .

83. See sources cited supra note 81 .

84. See sources cited supra note 80.

85. See Richard ScotT CARNEll ET AL., THE LAw OF FinANCIAL Institutions 65-91 (Rachel E. Barkow et al. eds., 6th ed. 2017) (providing background on what is a "bank" and the various forms of institutions).

86. See Telephone Interview with George Hofheimer, Owner, Hofheimer Strategy Advisors (May 19, 2021) [hereinafter Holfheimer] (discussing Hofheimer's experience and expertise in starting credit unions and the associated challenges, his work associated with the Equality Washington Credit Union, observations on why the Equality Washington effort failed, and general startup challenges specific to a LGBTQ+ focused credit union); see CARNELL ET AL., supra note 85 at 123-27 (discussing requirements to form a bank); Philip Rodney Moon, How to Start a Credit Union Bank, SAPLING, https:/www.sapling.com/6884454/start-credit-union-bank (last visited July 17, 2021) (providing summary of credit union startup requirements).

87. Moon, supra note 86 .

88. Id.

89. See sources cited supra note 86.

90. Hofheimer, supra note 86. 
its structure as a cooperative model; funding comes solely from member shareholders. ${ }^{91}$ Thus, the funding available to an LGBTQ+-focused credit union's funding from its members is likely to be tied to the interest and participation of members of the community and its allies, the target market.

Whether there is a large enough market for a LGBTQ+ community-focused institution (credit union or bank) will depend on the institution's reach, geographic location, and digital access and whether individuals can be convinced to forgo the benefits associated with conducting business with larger, more established institutions that have more physical locations and ATM access. ${ }^{92}$ While the relocation of many African Americans to northern cities after the Civil War ensured enough critical mass to support African American institutions, the experience of the short-lived DGACU suggests that there may be a smaller target for LGBTQ+ community banking. ${ }^{93}$

The DGACU's last NCUA Call Report stated that it "served 840 members and managed assets of $\$ 525,000,54$ loans valued at more than $\$ 337,000$, and total shares and deposits of $\$ 442,996 . "{ }^{94}$ Although the DGACU was created before the advent of the internet, it seems unlikely that e-commerce would mitigate the target market issue (while Daylight attempts to capitalize on a digital-only approach, it also relies on a partnership with another established bank. Thus, it is not a true independent bank that overcame the regulatory barriers to entry). ${ }^{95}$ Without enough funding to provide a substantial number of customers with lines of credit that can cover the cost of a mortgage, then a community-based institution risks losing some or all of an individual's business to other non-LGBTQ+ community-focused institutions that have the capital to provide those financial services. Consequently, without community institutions, efforts to prevent discrimination against the LGBTQ+ community may not be fully accomplished, particularly the type of experiences that the transgender community experiences.

The Rosa case highlights another instance of transgender discrimination. ${ }^{96}$ As a transgender woman in 1998, Rosa experienced discrimination because she dressed in a feminine manner and her identification documents listed her birth gender as male. ${ }^{97}$ When she went to a bank to request a mortgage application, the employee refused to provide the application until Rosa went home and changed

91. See sources cited supra note 90 .

92. See sources cited supra note 90.

93. BARADARAN, supra note 71 , at 69-83 (discussing African Americans migration to northern cities from 1910-70 influenced black community banks); Patrick Sisson, How Gay Bars Have Been a Building Block of the LGBTQ Community, CURBED (July 17, 2016, 11:11AM), https:// archive.curbed.com/2016/6/17/11963066/gay-bar-history-stonewall-pulse-lgbtq (describing factors that influenced LGBTQ+ community to congregate in large cities). But see Greggor Mattson, SmallCity Gay Bars, Big-City Urbanism, 19 SAGE J. CiтY \& CмтY 76, 76 (2020), https:// journals.sagepub.com/doi/epub/10.1111/cico.12443 (asserting impact of gay bars in small cities).

94. Strozniak, supra note 80.

95. Daylight, supra note 80 (stating FDIC deposit insurance is through MetaBank, N.A).

96. Rosa v. Park W. Bank \& Tr. Co., 214 F.3d 213 (1st Cir. 2000).

97. Id. at 214 . 
her clothes to something more masculine to conform with the gender on her identification. ${ }^{98}$ Rosa's initial complaint was dismissed at summary judgment; the first circuit granted her appeal by reversing and remanding, suggesting that ECOA might apply. However, the question of whether sexual orientation and gender identity were protected under ECOA was not fully resolved. ${ }^{99}$

That question arose again in 2007 when Adola DeWolf and Laura Watts, domestic partners, tried to modify DeWolf's mortgage to add Watts as a coowner. ${ }^{100}$ After the couple complied with the bank's directions, the bank notified the couple that adding Watts to the deed was unauthorized and "threatened to foreclose on the house if the almost $\$ 80,000$ balance on the mortgage was not paid in 30 days... [because the bank] did not recognize domestic partners as family." 101 This claim was settled though, so it did not resolve the question of whether sexual orientation and gender identity were protected as forms of sex discrimination under ECOA. ${ }^{102}$

Countless LGBTQ+ individuals have no doubt encountered discrimination that was similar to the experience of Rosa, DeWolf, and Watts in a "same script, different cast" manner. ${ }^{103}$ The transgender community is at particular risk for discrimination because of issues relating to names and identification. ${ }^{104}$ For example, if a credit application requires the disclosure of alias credit identities, the applicant would have to disclose their birth name, colloquially called a deadname, and if this deadname highlights that they were a different gender at birth, that can lead to discrimination based on gender identity. ${ }^{105}$ The second issue is that if the individual does not have identification that lists their name or gender in a way that conforms with how the individual presents (obtaining such updated identification is only possible in nineteen states), they may be denied credit. ${ }^{106}$

98. Id.

99. See generally Equal Credit Opportunity Act (ECOA), 15 U.S.C. § 1691; see also Equal Credit Opportunity Act (Regulation B), 12 C.F.R. § 1002 (2011); see Rosa, 214 F.3d 214 (displaying no subsequent case history in Westlaw or Lexis online resources after the 1 st Cir. decision).

100. DeWolf \& Watts Summary, supra note 4.

101. Id.

102. DeWolf \& Watts Summary, supra note 4; see also CFPB SAGE Letter, supra note 13.

103. Whitney Houston \& Deborah Cox, SAme Script, DifFErent CAST (Arista Records 2000) (providing phrase via song title and meaning via song lyrics).

104. Issues, Identity Documents \& Privacy, NAT'L CTR. FOR TRANSGENDER EQUAL., [hereinafter Transgender Identification] https://transequality.org/issues/identity-documents-privacy (last visited Apr. 18, 2021); See Jim Akin, How to Dispute a Name on your Credit Report, EXPERIAN: ASK EXPERIAN (Jun. 4, 2020), https://www.experian.com/blogs/ask-experian/how-to-dispute-aname-on-your-credit-report/ (discussing listing an individual's alternate names in a credit report).

105. Akin, supra note 104; Deadname, DiCTIONARY.COM, https://www.dictionary.com/e/popculture/deadname/ (last visited Apr. 17, 2021); see KC Clements, What is Deadnaming?, HEALTHLINE (Sept. 18, 2018) [hereinafter Clements Deadnaming] https://www.healthline.com/health/transgender /deadnaming (defining deadnaming and negative impacts of using a deadname).

106. Transgender Identification, supra note 104; Taylor Romine, New Jersey Ads ' $X$ ' gender marker on Drivers' Licenses and Other State Identification, CNN (Apr. 20, 2021), https:/www.cnn.com/2021/04/20/us/x-gender-drivers-license-new-jersey-trnd/index.html. 
Similar problems can arise in connection with the information contained in an individual's credit report. ${ }^{107}$ The experiences of Rosa, DeWolff \& Watts, and the hypotheticals discussed in Part III are all examples of discrimination that is unique to the LGBTQ+ community and clearly demonstrate the community's need for more concrete protections related to access to financial services.

\section{CFPB's Role in Consumer Finance}

The CFPB, an agency created by the Dodd-Frank Act in 2010, is the primary regulator for consumer financial protection. ${ }^{108}$ The CFPB has primary oversight over discrimination in financial services provided by larger banks and other nondeposit-taking financial institutions, like credit card companies and Quicken Rocket Mortgage. ${ }^{109}$ For banks that do not meet the statutory jurisdiction threshold of $\$ 10$ billion in assets, the institution's primary regulator, either the Office of the Comptroller of the Currency (OCC), the Federal Deposit Insurance Corporation, the Federal Reserve (FRB), or the National Credit Union Administration (NCUA), oversees compliance with fair lending laws and the CFPB's rules and regulations. ${ }^{110}$

In 2016, under former Director Richard Cordray, the CFPB indicated that their legal analysis supported the argument that ECOA applied to sexual orientation and gender identity as a form of sex discrimination. ${ }^{111}$ However, once President Trump was elected, it would have been highly unlikely for CFPB to refer any cases involving ECOA and discrimination based on sexual orientation and gender identity to DOJ, given then-Attorney General Sessions' Title VII guidance on what "based on sex" meant. ${ }^{12}$ After Cordray stepped down in November of 2017, and the CFPB's change in leadership to Acting Director Mick Mulvaney and then-Director Kathy Kraninger during the Trump administration,

107. Spencer Watson, Trans \& Queer Credit Reporting Issues, THE CTR. FOR LGBTQ ECON. ADVANCEMENT (Mar. 15, 2021), https://lgbtq-economics.org/2021/03/05/trans-queer-credit-report-issueswith-billie-simmons-from-daylight/?fbclid=IwAR2goybgqeO9Wvld7AD6Py-jTRNPM91cPRLD4jqyNC _ye-RDWNirvb44M18 (discussing obstacles and challenges for transgender individuals related to the information in their personal credit report reflecting their birth information, deadname and birth gender, and not the individual's actual identity).

108. See CARNELL ET AL., supra note 85 at $92-96$ (discussing U.S. financial regulators, their jurisdiction, and their missions).

109. See id. at 93 (discussing CFPB's financial regulation role); Leonard J. Kennedy et al., The Consumer Financial Protection Bureau: Financial Regulation for the Twenty-First Century, 97 CORNELl L. REV. 1141, 1144-46 (2012) (discussing CFPB's background and purpose); Patricia McCoy, Inside Job: The Assault on the Structure of the Consumer Financial Protection Bureau, 103 MinN. L. REV. 2543, 2610 (2019) (discussing CFPB's role in consumer protection).

110. See sources cited supra note 109.

111. CFPB SAGE Letter, supra note 13.

112. See CFPB SAGE Letter, supra note 13; Sessions Memo, supra note 13. 
it was unclear whether the CFPB maintained or rescinded its earlier position on sexual orientation and gender identity as a possible form of sex discrimination. ${ }^{113}$

\section{Potential Changes to Fair Lending Statutes OR REGULATIONS AND POSSIBLE IMPACTS}

Although addressing discrimination against the LGBTQ+ community is a relatively new application of fair lending law, an examination of the application of fair lending to other minority groups is instructive. ${ }^{114}$ All of these fair lending laws were passed after the Civil Rights Acts of 1957 and $1964 .{ }^{115}$ The majority of these laws were intended to supplement the two Civil Rights laws in achieving their purposes of battling discrimination. ${ }^{116}$ Many of the laws focused on mortgages and housing because buying a home is usually a consumer's most significant and expensive purchase, and all are supplemented by additional regulations and guidance promulgated by various financial regulators. ${ }^{117}$ Some of the statutes are universal; others are mortgage-specific. ${ }^{18}$ The statutes most relevant to the provision of financial services to the LGBTQ+ community are discussed here.

\section{A. The Community Reinvestment Act of 1977 (CRA)}

The CRA requires federal financial regulators to examine a financial institution's record of meeting the needs of all the individuals who live in the

113. See Barbara S. Mishkin, Second Circuit Decision Could Support ECOA Protection for Sexual Orientation, BAllard SPAHR, LlP: CONSUMER Fin. MONITOR (Feb. 28, 2018), https://www.consumerfinancemonitor.com/2018/02/28/second-circuit-decision-could-support-ecoaprotection-for-sexual-orientation/ (noting that since "President Trump's appointment of Mick Mulvaney as Acting Director, the CFPB ha[d] not yet taken a position on th[e] issue"). See generally Avie Schneider, Richard Cordray Stepping Down as Head of U.S. Consumer Protection Agency, NPR (Nov. 15, 2017, 1:25 PM), https://www.npr.org/sections/thetwo-way/2017/11/15/564349200/richardcordray-stepping-down-as-head-of-u-s-consumer-protection-agency; Emily Sullivan, Senate Confirms Kathy Kraninger as CFPB Director, NPR (Dec. 6, 2018), https://www.npr.org/2018/12/06 /673222706/senate-confirms-kathy-kraninger-as-cfpb-director. But see CFPB SAGE Letter, supra note 13.

114. See generally The Dodd-Frank Wall Street Reform and Consumer Protection Act (DoddFrank), Pub. L. No. 111-203 (2010). 15 U.S.C § 1639; 12 U.S.C. §§ 2601-2617; Home Mortgage and Disclosure Act (HMDA) of 1975, 12 U.S.C. $\S \S 2801-2810$; Community Reinvestment Act (CRA), 12 U.S.C § 2901; Equal Credit Opportunity Act (ECOA), 15 U.S.C. § 1691; Fair Debt Collection Practices Act of 1977 (FDCPA), 15 U.S.C. § 1692; Fair Housing Act (FHA), 42 U.S.C. §§ 3601-31.

115. See generally Real Estate Settlement Procedures Act of 1974 (RESPA), 12 U.S.C. $\S \S$ 2601-2617; Home Mortgage and Disclosure Act (HMDA) of 1975, 12 U.S.C. §§ 2801-2810; Community Reinvestment Act(CRA), 12 U.S.C § 2901; Truth in Lending Act of 1968 (TILA), 15 U.S.C. § 1601; Fair Credit Reporting Act (FCRA), 15 U.S.C. § 1681; Home Ownership and Protection Act of 1994 (HOEPA), 15 U.S.C. §1602; Equal Credit Opportunity Act (ECOA), 15 U.S.C. § 1691; Fair Housing Act (FHA), 42 U.S.C. $\S \S 3601-31$.

116. See id.

117. See id. See also CARNELL ET AL., supra note 85 at 551-52 (defining UDAP and UDAAP).

118. See sources cited supra notes $115,117$. 
institution's service area while balancing the institution's safety and soundness requirements. ${ }^{119}$ The CRA is one of the few consumer protection statutes that does not fall under the CFPB's jurisdiction. ${ }^{120}$

Part of the reason for passing the CRA in 1977 was to eliminate the practice of redlining. ${ }^{121}$ First defined in the 1960s, redlining is "an illegal practice where people living in a certain area or neighborhood are not given the same access to credit as people in other areas or neighborhoods based on... [a] prohibited reason. Though the practice has been illegal for decades, it still goes on today." 122 While discrimination on the basis of geographic location is not prohibited in and of itself, the purpose of redlining was usually to avoid neighborhoods where the residents were mostly racial minorities or had some other protected status. ${ }^{123}$ If the reason for avoiding a geographic location is purely to avoid a protected class, then the redlining is an illegal activity. ${ }^{124}$ However, if an institution decides not to offer loans to anyone from specific neighborhoods and the residents of those neighborhoods are mostly racial minorities, a seemingly neutral geographic policy would have a disparate impact of discriminating based on race. ${ }^{125}$ Conversely, if an institution targets a neighborhood to charge higher rates or provide access to financial services on unfair terms, the action is known as reverse redlining. ${ }^{126}$

While there is not a direct enforcement mechanism for a violation of the CRA, there are negative consequences if a bank's CRA record is poor. ${ }^{127}$ The bank's regulator will consider the bank's CRA record in the context of any actions that require the regulator's approval and can use an unacceptable CRA record to deny requests that require regulatory approval. ${ }^{128}$ Such requests might relate to expansion or closing plans, appointing new board members, or changing the

119. CARNELL ET AL., supra note 85 at 562-71 (providing background on CRA's purpose, its financial regulation role, and "the appropriate Federal financial supervisory agencies" enforce it); see Kennedy et al., supra note 109 at 1148-49 (discussing CFPB's jurisdiction and the associated statutes).

120. Id.

121. Daniel Dodd-Ramirez \& Patrice A. Ficklin, Redlining: CFPB and DOJ Action Requires BancorpSouth Bank to Pay Millions to Harmed Consumers, Consumer Fin. Protection Bureau: BLOG (Jun. 29, 2016), https://www.consumerfinance.gov/about-us/blog/redlining-cfpb-and-dojaction-requires-bancorpsouth-bank-pay-millions-harmed-consumers/ (defining redlining). See Adam Hayes, Redlining, INVESTOPEDIA [hereinafter Redlining] https://www.investopedia.com/terms/r /redlining.asp (last visited Nov. 2019) (providing background on redlining and reverse redlining).

122. Dodd-Ramirez \& Ficklin, supra note 121; see Redlining, supra note 121.

123. See Dodd-Ramirez \& Ficklin, supra note 121; see Redlining, supra note 121.

124. Dodd-Ramirez \& Ficklin, supra note 121; Redlining, supra note 121.

125. See Mayer Brown, CFPB Sues First Non-Bank Mortgage Lender for Alleged Redlining, Fair Lending Newsletter Fall 2020 at 7.

126. See Dodd-Ramirez \& Ficklin, supra note 121 (defining redlining); Redlining, supra note 121.

127. See Dodd-Ramirez \& Ficklin, supra note 121 at 19; see Redlining, supra note 121.

128. CARNELL ET AL., supra note 85, at 562 (discussing CRA approval requirement for any action that requires approval of financial institution's primary regulator). 
home office or individual branch locations. ${ }^{129}$ Should sexual orientation and gender identity gain explicit protection, a financial institution that exhibits behavior indicative of the new forms of redlining or reverse redlining against the LGBTQ+ community faces a serious business risk. ${ }^{130}$

\section{B. The Equal Credit Opportunity Act (ECOA)}

Effective in 1974, ECOA "prohibits discrimination in lending on the basis of race, color, religion, national origin, sex, marital status, or age, or because a person receives public assistance or has exercised a right under certain consumer protection laws." ${ }^{131}$ Regulation B provides the rules that institutions must comply with to avoid violating ECOA. ${ }^{132}$ Since the authority for enforcing ECOA was transferred from FRB to the $\mathrm{CFPB}$, the CFBP has vigorously asserted that redlining is a violation of ECOA. ${ }^{133}$

If an institution engages in redlining or reverse redlining, the institution could be at risk of an ECOA violation in addition to having CRA problems. ${ }^{134}$ The CFPB has pursued cases where an institution inappropriately excluded minority neighborhoods from its service area. ${ }^{135}$ Naturally, any action with the actual intent to discriminate is a violation of ECOA. ${ }^{136}$ Additionally, practices that appear to be facially neutral but have a discriminatory effect or impact, known as disparate impact or treatment, can also trigger an ECOA violation. ${ }^{137}$ However, there is an exception for a bona fide credit underwriting standard that may have such a disparate impact. ${ }^{138}$ One noteworthy case was the CFPB's claim against BancorpSouth Bank, in which the CFPB alleged that the entity "was illegally

129. See id.

130. See Redlining, supra note 121; Sun \& Gao, supra note 8; see infra Part III Sections b-c, g.

131. Kennedy et al., supra note 109 at 1148 (describing ECOA's purpose); see Equal Credit Opportunity Act (ECOA), 15 U.S.C. $\$ 1691$.

132. Equal Credit Opportunity (Regulation B); 86 Fed. Reg. 14363 (Mar. 16, 2021) (to be codified at 12 C.F.R. pt. 1002); CFPB ECOA Announcement, supra note 18.

133. Justice Department and Consumer Financial Protection Bureau Reach Settlement with BancorpSouth Bank to Resolve Allegations of Mortgage Lending Discrimination, DEP'T OF JUST.: JUSTICE NEWS (June 29, 2016) [hereinafter ECOA Redlining] https://www.justice.gov/opa/pr/justicedepartment-and-consumer-financial-protection-bureau-reach-settlement-bancorpsouth (announcing settlement and consent order under ECOA related to redlining actions); CARNELL ET AL., supra note 85, at 512 (discussing redlining under CRA and CFPB's interpretation it violates ECOA); see DoddRamirez \& Ficklin, supra note 121, at 19.

134. See ECOA Redlining, supra note 133; CARNELL ET AL., supra note 85, at 512 (providing redlining background and CFPB's claim it violates ECOA); see generally Equal Credit Opportunity Act (ECOA), 15 U.S.C. $§ 1691$; Kennedy et al., supra note 109, at 1148 (providing ECOA's purpose).

135. See ECOA Redlining, supra note 133; CARNELL ET AL., supra note 85, at 512; DoddRamirez \& Ficklin, supra note 121.

136. See 15 U.S.C. $§ 1691$; Kennedy et al., supra note 109 at 1148 .

137. CARNELL ET AL., supra note 85, at 509 (discussing proof of direct harm not necessary and disparate impact gives standing for discrimination claim).

138. Id. (stating bona fide underwriting standards that result in a disproportionate rate for the denial of credit to a protected class may be permissible under the effects test). 
redlining predominantly minority neighborhoods in" Memphis; the result was a settlement of $\$ 10$ million in monetary relief and the institution's commitment to spend at least $\$ 800,000$ on community outreach programs. ${ }^{139}$ Institutions not under the CFPB's jurisdiction face the same risk if their primary regulator adopts CFPB's approach. ${ }^{140}$ For example, a regulator might find that an institution discriminates against heterosexuals by charging them more interest for living in a gay neighborhood and then pursue a reverse redlining claim against the institution. In doing so, the regulator would establish that redlining against the LGBTQ+ community violates ECOA. ${ }^{141}$

Beyond redlining, there are other ways for a financial institution to become liable for an ECOA violation. ${ }^{142}$ Individual lending decisions based on a protected status like race, gender, or marital status are all prohibited. ${ }^{143}$ ECOA caps a claim for a single violation at $\$ 10,000$ and caps class action lawsuits at the lesser of $\$ 500,000$ or one percent of the institution's net worth. ${ }^{144}$ Thus, a financial institution that violates ECOA could face an enforcement action from a regulator, a private claim from an impacted individual, or a class-action claim from a group of impacted individuals. ${ }^{145}$

In 2013, the CFPB ordered one financial institution to pay $\$ 80$ million in damages for a violation of ECOA in addition to $\$ 18$ million in penalties. ${ }^{146}$ Now that sexual orientation and gender identity have protection under ECOA as a result of CFPB's interpretive rule, any institution that charges an applicant a higher level of interest because of the applicant's sexual orientation or gender identity might face similar penalties. ${ }^{147}$ Since ECOA creates liability for intentional discrimination as well as disparate impact, institutions risk legal action for any intentional discriminatory actions based on sexual orientation or gender identity and for any seemingly facially neutral policy that has a disproportionate impact based on either trait. ${ }^{148}$ The CFPB's interpretive rule also addresses the

\footnotetext{
139. ECOA Redlining, supra note 133.

140. See sources cited supra note 134 .

141. See sources cited supra note 134 .

142. See 15 U.S.C. $§ 1691$ (establishing ECOA's scope and civil liabilities); see also 12 C.F.R. $\S 1002.16$ (2021) (defining ECOA's enforcement penalties and liabilities).

143. See 12 C.F.R. $§ 1002.16$ (2021) (defining ECOA's enforcement penalties and liabilities).

144. See $i d$.

145. See id; see also 15 U.S.C. $\$ 1691$ (establishing ECOA's scope and civil liabilities).

146. CFPB and DOJ Order Ally to Pay $\$ 80$ Million to Consumers Harmed by Discriminatory Auto Loan Pricing, Consumer Fin. Prot. Bureau (Dec. 20, 2013) [hereinafter ECOA Offense] $\mathrm{https}$ //www.consumerfinance.gov/about-us/newsroom/cfpb-and-doj-order-ally-to-pay-80-million-toconsumers-harmed-by-discriminatory-auto-loan-pricing/, (illustrating penalties against Ally Financial and Ally Bank for violation of ECOA).

147. See id.; Equal Credit Opportunity (Regulation B); 86 Fed. Reg. 14363 (Mar. 16, 2021) (to be codified at 12 C.F.R. pt. 1002); CFPB ECOA Announcement, supra note 18.

148. CARNELL ET AL., supra note 85, at 509 (discussing proof of direct harm not necessary and disparate impact gives standing for discrimination claim); see sources cited supra notes 146-147.
} 
type of discrimination that Ms. Rosa, DeWolf, and Watts experienced: according to the CFPB, these actions now violate ECOA. ${ }^{149}$

Under the Biden Administration, the CFPB may choose to build on its current informal interpretive rule with additional interpretive or formal rules. ${ }^{150}$ One possibility could be the required rulemaking under section 1071 of Dodd-Frank, which deals with small-business lending data. ${ }^{151}$ Should sexual orientation and gender identity become data points that must be reported in accordance with section 1071, financial institutions can be held liable under the ECOA interpretive rule if that data suggests discrimination based on either status that impacts LGBTQ+ small businesses. Other sources of data, including those collected under HMDA, may also inform enforcement actions under the new interpretive rule. ${ }^{152}$

\section{The Home Mortgage Disclosure Act (HMDA)}

HMDA requires most lenders to collect, maintain, and report data about their mortgage lending. ${ }^{153}$ The HMDA datasets serve as a vital source of information to federal regulators and the general public, enabling them to identify potential discrimination. ${ }^{154}$ The current HMDA datasets consist of forty-eight data points (including loan type, amount, property address, and applicant's race, ethnicity, and sex) that include certain protected statuses. ${ }^{155}$ During Cordray's leadership, the CFPB designated new mandatory HMDA data points (total points and fees, loan term, loan originator ID, property value, and credit score), some of which are mandated by Dodd-Frank and others designated through CFPB's discretionary power. ${ }^{156}$ However, just before the requirement went into effect in 2018, the Republican-controlled Congress enacted regulatory relief that exempted eighty-five percent of banks from reporting the HMDA data points mandated by Dodd-Frank. ${ }^{157}$ Under Acting Director Mulvaney, the circumvention was expanded when the CFPB adopted "an interpretive and

149. See CFPB ECOA Announcement, supra note 18.

150. See infra Part IV Section b.

151. See Small Business Lending Data Collection Rulemaking, CONSUMER Fin. Prot. BUREAU, https://www.consumerfinance.gov/1071-rule/ (last visited Apr. 10, 2020) (documenting purpose of CFPB's rulemaking for section 1071 of Dodd-Frank and rulemaking's status in the process).

152. See infra Part III Sections c, g.

153. Kennedy et al., supra note 109 at 1149 (explaining HMDA).

154. Id.; see McCoy, supra note 109 at 2581-82 (discussing HMDA data set importance and arbitrage of new data point regulation).

155. Consumer Fin. Prot. Bureau, Reportable hMda data: A Regulatory and REPORTING OVERVIEW REFERENCE CHART, 3-5, 8, 11, 16 (2020) [hereinafter HMDA Data List] https:// files.consumerfinance.gov/f/documents/cfpb_reportable-hmda-data_regulatory-and-reporting-overviewreference-chart-2019.pdf (listing and defining current HMDA data points).

156. 80 Fed. Reg. 66287 n. 501 (Oct. 28, 2015) (listing Dodd-Frank mandated HMDA data points); McCoy, supra note 109 at 2581-82

157. Id. at 2582 . 
procedural rule" that exempted most of the same institutions from reporting the new discretionary data points. ${ }^{158}$

Although HMDA data does not include sexual orientation or gender identity, there are three studies, two academic ones by Dillbary \& Edwards and Sun \& Gao, and one by the National Community Reinvestment Coalition (NCRC), that used HMDA data to identify indicators of potential discrimination against the LGBTQ+ community for mortgage loans. ${ }^{159}$ Dillbary \& Edwards found that compared to white heterosexual applicants, applications from "same-sex male coapplicants ... are between 2.5 and 7.5 percentage points less likely to" be approved and that the denial rates were higher for minority and mixed-race couples, with additional variability based on the race of the primary applicant. ${ }^{160}$ Female co-applicants appeared to be treated the same but replicated the same race-based issues as the findings for men. ${ }^{161}$ Both the NCRC and Sun \& Gao studies found that same-sex applicants were charged higher interest rates than heterosexual borrowers, and Sun \& Gao found a specific range of 0.02-0.20 percent. ${ }^{162}$ Additionally, the Sun \& Gao study asserted that there are spillover effects that impact heterosexual couples residing in neighborhoods with a higher population of same-sex couples, an indicator of reverse redlining. ${ }^{163}$ Finally, the Sun \& Gao study also developed a proposed method to infer sexual orientation for identifying discriminatory practices. ${ }^{164}$ They proposed this method as an alternative to asking applicants to "out" themselves by disclosing their sexual orientation and gender identity. ${ }^{165}$

However, because sexual orientation and gender identity are not HMDA data points, the studies had to infer sexual orientation, all based on an initial assumption that same-sex applicants were LGBTQ+ couples. ${ }^{166}$ Their findings are sufficient for academic purposes and a legal claim about discrimination based on sex but may not be enough for a legal claim related to LGBTQ+ discrimination; the result of this is the chance of such claims being dismissed (Federal Rules of Civil Procedure 12(b)(6) and 56). ${ }^{167}$ To have a concrete finding

158. Id.

159. See Dillbary \& Edwards, supra note 8 at 4 (using HMDA data to identify trends of LGBTQ+ discrimination in lending); Sun \& Gao, supra note 8; Richardson \& Kali, supra note 8; Lederer \& Lilien, supra note 8.

160. Dillbary \& Edwards, supra note 8 at 5-6.

161. Dillbary \& Edwards, supra note 8 at 6.

162. Sun \& Gao, supra note 8 .

163. Sun \& Gao, supra note 8; see Redlining, supra note 121.

164. Sun \& Gao, supra note 8 .

165. Id.; see infra Part V Section c.

166. HMDA Data List, supra note 155 (omitting sexual orientation and gender identity); Richardson \& Kali, supra note 8 (stating no way to identify same-sex couples using HMDA data); Sun \& Gao, supra note 8 (stating no requirement to disclose sexual orientation).

167. See FED. R. CIV. P. 12(b)(6), 56; Ashcroft v. Iqbal, 556 U.S. 662, 687 (2009) (finding complaint must plead sufficient facts to state a claim); Bell Atl. v. Twombly, 550 U.S. 544, 566 (2007) (finding claim must put forward enough factual information that is plausible discovery will reveal 
requires data that reflects the actual sexual orientation and gender identity of the consumers. ${ }^{168}$

Under the Biden Administration, it is possible that sexual orientation and gender identity could become HMDA data points in a future update. ${ }^{169}$ If this happens, it is probable that, like race and gender, consumers will not have to disclose their sexual orientation and gender identity as mandatory data points, but institutions will have to report any data that is voluntarily disclosed. ${ }^{170}$ Should an institution be found to have falsified these data points, the institution would also be subject to penalties. ${ }^{171}$ Additionally, intentional manipulation of HMDA data could result in penalties under ECOA. ${ }^{172}$ If it is possible to correct the manipulated HMDA data, the result could reveal discriminatory lending practices that violate ECOA. ${ }^{173}$ Should the data correction reveal an ECOA violation, the institution could face enforcement action from the CFPB, the institution's primary regulator, or individual claims from applicants because ECOA allows private claims, or a combination of claims. ${ }^{174}$

To provide an example of the potential consequence of HMDA violations, in the summer of 2019, CFPB took enforcement action against a lender, Freedom Mortgage Corporation, one of the ten largest HMDA reporters. ${ }^{175}$ For the years between 2014-2017, the lender inaccurately reported HMDA data in addition to falsifying HMDA data when applicants chose not to disclose their race or ethnicity. ${ }^{176}$ While the action did not go to trial because the lender decided to settle the case, it had to work to improve its compliance program and pay a civil penalty of $\$ 1.75$ million for the reporting inaccuracies. ${ }^{177}$

evidence); Richardson \& Kali, supra note 8 (providing the study's methodology); Dillbary \& Edwards, supra note 8 at 4-5 (discussing how HMDA allowed analysis based on perceived LGBQ+ couples); Sun \& Gao, supra note 8, at 9295 (overestimating by assuming all same-sex applicants are LGBTQ+).

168. See sources cited supra note 167.

169. See infra notes 272-278 and accompanying text.

170. See HMDA Data List, supra note 155, at 11-17 (demonstrating applicants not required to disclose race or gender and providing guidance to financial institutions on reporting race and gender based on if the applicant did or did not disclose).

171. See Consumer Financial Protection Bureau Settles with Freedom Mortgage Corporation, Consumer Fin. Prot. Bureau (June 05, 2019) [hereinafter HDMA Offense], https:// www.consumerfinance.gov/about-us/newsroom/bureau-settles-freedom-mortgage-corporation/.

172. See Equal Credit Opportunity Act (ECOA), 15 U.S.C. § 1691; Kennedy et al., supra note 109, at 1148 (providing ECOA's purpose); CARNELL ET AL., supra note 85, at 509 (discussing proof of direct harm not necessary and disparate impact gives standing for discrimination claim).

173. 15 U.S.C. $\S 1691$ (e); see also 12 C.F.R. § 1002.16 (2021).

174. 15 U.S.C. $\S 1691$ (e); 12 C.F.R. $\S 1002.16$ (2021)

175. See HDMA Offense, supra note 171.

176. Id

177. Id 


\section{The Fair Housing Act (FHA)}

The FHA prohibits taking actions based on race, color, national origin, religion, sex, familial status, or handicap status for various mortgage financing and insurance-related activities, including terms, conditions, valuation, and certain underlying factors and data points. ${ }^{178}$ This prohibition also covers the loan purchasing activities of financial institutions. ${ }^{179}$ The Department of Housing and Urban Development (HUD), not CFPB, enforces the FHA. ${ }^{180}$ However, because there is an overlap between the FHA and the statutes under CFPB's jurisdiction, discriminatory actions related to mortgage financing could result in enforcement actions from one or both agencies, either individually or by joint action. ${ }^{181}$

The LGBTQ+ community already has some protections under the FHA via HUD's 2012 Equal Access Rule, a formal rule adopted through the notice and comment process. ${ }^{182}$ The rule prohibits discrimination against members of the community in access to any HUD program, like the FHA's mortgage insurance programs. ${ }^{183}$ After Bostock, HUD issued a policy memo, the equivalent of an informal interpretive rule, to implement the guidance in Executive Order 13,988. ${ }^{184}$ Acting Assistant Secretary Worden for HUD's Office of Fair Housing and Equal Opportunity (FHEO) stated that the scope of the Equal Access Rule was too narrow to properly comply with the guidance in EO 13,988. ${ }^{185}$ Next, the memo stated that FHEO would accept all complaints of discrimination based on sexual orientation or gender identity within its jurisdiction. ${ }^{186}$ Finally, the memo outlined other FHEO policy changes related to activities that intersect with the FHA's prohibition on sex discrimination, investigations of complaints with multiple protected statuses, and the impact on agreements with state or local agencies and non-government entities that work with HUD. ${ }^{187}$ Thus, it is possible that HUD will take additional steps to implement EO 13,988, clarify FHEO's

\footnotetext{
178. Fair Housing Act (FHA), 42 U.S.C. $\S \S 3601-31$.

179. Id.

180. Id. at $\S 3608$.

181. See 15 U.S.C. § 1691(e); 12 C.F.R. § 1002.16 (2021); see supra notes 133-149 and accompanying text; Kennedy et al., supra note 109, at 1148 (providing ECOA's purpose).

182. See Equal Access to Housing in HUD Programs Regardless of Sexual Orientation or Gender Identity, 77 Fed. Reg. 5662, 5662 (Feb. 03, 2012) [hereinafter 2012 Equal Access Rule] (codified at 24 C.F.R. pts. 5, 200, 203, 236, 400, 570, 574, 882, 891, 892) (summarizing Equal Access Rule's purpose was to prevent discrimination against LGBTQ+ consumers in access to HUD programs).

183. Id.

184. See EO 13,988, supra note 15; Memorandum from Jeanine M. Worden, Acting Assistant Sec'y for Fair Hous. \& Equal Opportunity, U.S. Dep't of Hous. and Urb. Dev., to Off. Of Fair Hous. \& Equal Opportunity; Fair. Hous. Assist. Prog. Agencies; U.S. Dep't Hous. and Urb. Dev., Fair Hous. Initiatives Program Grantees (Feb. 11, 2021) [hereinafter HUD Memo], https://www.hud.gov/sites /dfiles/FHEO/documents/WordenMemoEO13988FHActImplementation.pdf; see infra Part IV Section $b$.

185. HUD Memo, supra note 184, at 2.

186. Id. at 2 .

187. Id. at 2-3.
} 
policy memo, or take joint action with CFPB if there is a statute that requires inter-agency collaboration to promulgate a rule.

\section{E. The Fair Credit Reporting Act (FCRA)}

The FCRA establishes requirements and governs the behavior of consumer reporting agencies (CRAs), entities that use credit reports, and entities that furnish information (furnisher(s)) to the CRAs. ${ }^{188}$ Access to credit reports is restricted to individuals who have a specific need for the information, and if the user of credit information takes an adverse action based on information in a credit report, the user must notify the consumer and provide a copy of the report. ${ }^{189}$ The adverse action requirement is universal and applies to actions relating to existing credit relationships as well as new credit applications. ${ }^{190}$

The FCRA also entitles consumers to obtain a free copy of their credit report once a year from each of the three nationwide credit bureaus. ${ }^{191}$ Should a consumer discover incorrect information in their report, the reporting agency is obligated to make reasonable efforts to work with the consumer to remediate the situation and notate that the item is in dispute on the credit report until the issue is resolved. ${ }^{192}$ However, what constitutes a reasonable effort is not defined. ${ }^{193}$ Usually, remediation of incorrect information involves interacting with the information's furnisher since the FCRA legally requires a furnisher to provide accurate information to CRAs. ${ }^{194}$ When a consumer contacts a furnisher about incorrect data, the furnisher must conduct a reasonable investigation and, if the information is incorrect, correct the issue with the appropriate CRAs. ${ }^{195}$ However, like the requirement for CRAs, what is a "reasonable investigation" is not defined. ${ }^{196}$

Outside of correcting the information, there are few remedies for FCRA violations. ${ }^{197}$ There is no private right of action if a user of credit information takes an adverse action and does not give the consumer a copy of the credit report. ${ }^{198}$ Additionally, consumers cannot make a private claim against furnishers

188. Fair Credit Reporting Act, 15 U.S.C. $\S 1681$

189. Id. at $\S \S 1681 \mathrm{~b}, \mathrm{~m}(\mathrm{a})$.

190. See Safeco Ins. Co. of America v. Burr, 551 U.S. 47, 60-63 (2007) (holding adverse actions can happen with initial applications for credit).

191. See sources cited supra note 109.

192. 15 U.S.C. $\S 1681 \mathrm{c}(\mathrm{f})$; CARNELL ET AL., supra note 85, at 521-22 (discussing CRA obligations for disputes to items on a consumer's credit report).

193. See sources cited supra note 192 .

194. See id. § 1681s-2(a).

195. 15 C.F.R. $\S 1022.43$.

196. Id.

197. See CARNELL ET AL., supra note 85, at 528 (discussing remedies for FCRA violations).

198. See 15 U.S.C. $\S 1681 \mathrm{~m}(\mathrm{~h})$. 
under federal or state law. ${ }^{199}$ Some provisions of the FCRA can be enforced via civil action, usually when there is a willful or negligent violation, and consumers may be eligible to recover damages with a cap and reasonable attorney's fees and costs. ${ }^{200}$ However, some courts allow plaintiffs to circumvent the caps via damages for emotional harm or distress. ${ }^{201}$

While FCRA's purpose is not about combating discriminatory lending practices, if the CFPB required the collection of sexual orientation and gender identity data, it is possible that the credit reporting agencies could start collecting and reporting the data as well. Should the CRAs report these new data points, the FCRA could serve as another source of data for identifying discriminatory practices against the LGBTQ+ community. Additionally, if furnishers and CRAs begin to collect and report sexual orientation and gender identity, there could be liability related to adverse actions for willful or negligent disclosure of the data. ${ }^{202}$ With regard to transgender individuals specifically, there can be issues if the credit report reflects the individual's birth gender or deadname. ${ }^{203}$ Because credit reports are commonly pulled for any application for credit, and sometimes for housing applications, the conspicuous discrepancy related to gender information and deadname could easily facilitate an act of discrimination that could ultimately be remedied under the FCRA and ECOA. ${ }^{204}$

\section{F. The Fair Debt Collection Practices Act (FDCPA)}

Enacted in 1977, the FDCPA provides protection to consumers by creating certain standards of conduct for debt collectors. ${ }^{205}$ Debt collectors are defined as any individual who collects debt on behalf of another party, so the FDCPA does not apply to a financial institution with its own internal debt collection group. ${ }^{206}$ These protections include a prohibition on making false representations; harassing the consumer at work, in public, and at unreasonable hours; using obscene language; and using or threatening violence. ${ }^{207}$

In addition to enforcement by a federal regulator, consumers have a private right of action for a violation of the FDCPA that can provide damages representing the actual monetary loss that resulted from the harmful act and

199. See Purcell v. Bank of America, 659 F.3d 622, 625-26 (7th Cir. 2011) (holding that the FCRA preempts state law claims based on reporting information to consumer reporting agencies); accord Macpherson v. JPMorgan Chase Bank, 665 F.3d 45, 48 (2d Cir. 2011).

200. 15 U.S.C. $\S \S 1681 \mathrm{n}$, o.

201. CARNELL ET AL., supra note 85, at 528 (discussing remedies for FCRA violations).

202. See id.

203. See sources cited supra notes 104, 107; see also Clements Deadnaming, supra note 105.

204. See sources cited supra note 203; see also sources cited supra notes 131-152 and accompanying text.

205. See Fair Debt Collection Practices Act, 15 U.S.C. § 1692.

206. See id. § 1692a.

207. Id. $\S 1692 \mathrm{c}-\mathrm{e}$. 
reasonable attorney's fees. ${ }^{208}$ The FDCPA allows for extra damages for individual and class action claims based on the frequency and nature of noncompliance and if the actions were intentional. ${ }^{209}$ Finally, FDCPA violations are also unfair or deceptive acts or practices under UDAP and UDAAP (which will be discussed shortly), creating the risk of individual or joint enforcement from the FTC and CFPB. ${ }^{210}$

While the FDCPA language does not explicitly mention protected status, it is possible for actions based on protected status to trigger a violation of the FDCPA. ${ }^{211}$ Hate language against the LGBTQ+ community while attempting to collect the debt could qualify as obscene language. ${ }^{212}$ Additionally, should the debt collector know that the individual is not out, threats of outing or confronting the individual in public while referencing their sexual orientation or gender identity would qualify as harassment. ${ }^{213}$ Finally, a court may consider actions that are based on a protected status as aggravating factors for awarding additional damages. ${ }^{214}$

\section{G. Unfair, Deceptive Acts and Practices (UDAP) and \\ Unfair, Deceptive or Abusive Acts and Practices (UDAAP)}

CFPB has primary authority in defining and regulating UDAAP. ${ }^{215}$ UDAAP grew out of the original term "Unfair or Deceptive Acts and Practices" (UDAP), introduced by the Wheeler-Lee Act of 1938 that modified the Federal Trade Commission Act (FTC Act) of 1914. ${ }^{216}$ After the 2007 financial crisis, Section 1031 of Dodd-Frank added the term "abusive" to create UDAAP and delegated authority to CFPB. ${ }^{217}$

\section{i. UDAP}

The FTC still has responsibility for UDAP, and the FTC's guidance on the definitions of unfair and deceptive and the associated case law also applies to UDAAP. ${ }^{218}$ The unfairness standard originates from Section 5 of the FTC Act (enacted as Section 45), but additional guidance comes from In the Matter of Int'l 
Harvester Co ${ }^{219}$ The unfairness standard is a three-pronged test that consists of the following: (1) an act or practice causes or is likely to cause substantial injury, (2) consumers cannot reasonably avoid the injury, and (3) the injury is not outweighed by countervailing benefits to consumers or to competition. ${ }^{220}$ One example of such a violation would be an app store refusing to provide a refund after a child is able to use their parent's phone to go on an accidental shopping spree because a password was not required after an initial purchase. ${ }^{221}$

The deception standard comes from Section 5 of the FTC Act, the administrative decision in Cliffdale Associates, Inc. ${ }^{222}$ and a policy statement from the FTC that appended Cliffdale. ${ }^{223}$ The deception standard is a threepronged test requiring: (1) a representation, omission, or practice, express or implied (including partial omissions), that is likely to mislead; (2) a targeted consumer acting in a reasonable manner for the circumstances, and (3) the action in question must be material, i.e., likely to influence the consumer's choice. ${ }^{224}$ Under Cliffdale, the second prong creates liability for any reasonable response to the facts. ${ }^{225}$

Most of the FTC deception case law revolves around issues like hidden fees, required information being dispersed across documents making it difficult for a consumer to compile and understand, and misrepresentations or false assertations about the product or service. ${ }^{226}$ However, deception can also relate to data collection and usage. For example, the FTC brought an action against a mobile phone app developer who created a seemingly harmless flashlight program that accessed data on the user's phone without their knowledge or permission and sent information back to the developer. ${ }^{227}$

There have been many enforcement actions against financial service providers for things like hidden fees, lack of notice on transaction restrictions, and distribution of consumer financial transaction data. ${ }^{228}$ For example, in 2018,

219. 15 U.S.C. $\S 45(a)$; In re Int'l Harvester Co., 104 F.T.C. 949 (1984).

220. See sources cited supra note 219; 15 U.S.C. $\S 45(n)$ (stating standard of proof).

221. FTC v. Amazon.com, Inc., No. C14-1038-JCC, 2016 WL 10654030, at *8-12 (W.D. Wash. July 22, 2016) (finding not refunding unauthorized app store charges by children and not placing proper precautions to prevent such charges a violation of unfairness standard).

222. Cliffdale Assocs., 103 F.T.C. 110, 164-65 (1984).

223. Robert Freer, Commissioner, FTC, Address before the Proprietary Association: the Wheeler-Lea Act (May 17, 1938) (creating UDAP authority by amending section 5 of FTC Act); see 15 U.S.C. $§ 45$ (a); Cliffdale Assocs., 103 F.T.C. 110at (finding liability for disseminating deceptive advertisements).

224. Cliffdale Assocs., 103 F.T.C. at 165 (1984)

225. Id

226. See e.g., F.T.C. v. AMG Servs., Inc., 29 F.Supp.3d 1338 (D. Nev. 2014) (charging multiple finance fees when advertised only one fee); see also, e.g., Goldenshores Technologies, LLC., C-4446 (FTC 2014) (decision and order) (finding flashlight app accessed and shared data from user's device to vendor without any notice or consent was deceptive).

227. Goldenshores Technologies, LLC., C-4446 (FTC 2014) (decision and order).

228. See id.; see Paypal, Inc., C-4651 (FTC 2018) (complaint) (finding Venmo's act of delaying required verifications of transactions until user requested funds be sent to their bank account resulting 
the FTC and CFPB took action against PayPal for the actions of its subsidiary company, Venmo. ${ }^{229}$ The first issue was that Venmo did not conduct the required verifications for transactions between users until a user requested that the funds be transferred to their bank, which resulted in reversals of transactions that the consumer thought were completed. ${ }^{230}$ In other words, the consumer was deceived into thinking that they had the funds in their Venmo account. ${ }^{231}$ The second issue involved transaction history privacy. ${ }^{232}$ Every Venmo transaction has a privacy option: public, visible to friends, or private and only visible to the two users. ${ }^{233}$ However, Venmo did not notify users that both parties needed to take action to make a transaction private; a user's action only impacted their friends, and friends of a user who did not mark the transaction as private could still see it. ${ }^{234}$

Recently, the FTC issued informal guidance indicating that the actions of AIs that result in discrimination based on race are illegal UDAP actions, supporting a line of legal argument that some consumer advocates have started to make. ${ }^{235}$ If an AI's actions against one protected class can be discriminatory and illegal, it is possible that this line of reasoning could be extended to the LGBTQ+ community. ${ }^{236}$

Concrete protections under UDAP could create liability for financial institutions if they engaged in activities like advertising as LGBTQ+ friendly but charging those consumers more for financial services compared to other similarly

in reversal of improper transactions and requiring both parties to designate a transaction as private while not notifying users of the requirement was deceptive).

229. Paypal, Inc., C-4651 (FTC 2018) (complaint).

230. Id. at paras. $10-16$.

231. Id.

232. Id. at paras. $17-34$.

233. Id.

234. Id

235. See, e.g., Elisa Jillson, Aiming for Truth, Fairness, and Equity in Your Company's Use of AI, FTC (Apr. 19, 2021), https://www.ftc.gov/news-events/blogs/business-blog/2021/04/aimingtruth-fairness-equity-your-companys-use-ai; Ian Weiner, FTC Declares Racially Biased Algorithms in Artificial Intelligence Unfair and Deceptive, Prohibited by Law, LAW's COMM. FOR C. R. UNDER L. (Apr. 20, 2021), https://lawyerscommittee.org/ftc-declares-racially-biased-algorithms-in-artificialintelligence-unfair-and-deceptive-prohibited-by-law/; STUDENT BORROWER PROTECTION CTR. (SBPC), DISCRIMINATION IS "UNFAIR" INTERPRETING UDA(A)P TO PROHIBIT DISCRIMINATION 4 (2021) [hereinafter "SBPC UDAP”], https://protectborrowers.org/wp-content/uploads/2021/04 /Discrimination_is_Unfair.pdf (asserting that an AI's actions that discriminate against a protected class qualifies as UDAP); Stephen Hayes \& Kali Schellenberg, Leveraging UDA(A)P in the Fight Against Discrimination, SBPC (Apr. 22, 2021) https://protectborrowers.org/leveraging-udaap-in-thefight-against-discrimination/ (discussing SBPC Report on AI and UDAP); SBPC, EDUCATIONAL REDLINING, 15-19, (Feb. 2020) [hereinafter “Upstart Report”], https://protectborrowers.org/wpcontent/uploads/2020/02/Education-Redlining-Report.pdf (asserting discrimination in AI decisions for student loans).

236. See Jillison, supra note 235; see SBPC UDAP, supra note 235; see Hayes \& Schellenberg, supra note 235; see Upstart Report, supra note 235. 
situated heterosexual applicants. ${ }^{237}$ This type of action would qualify as a violation of both the unfairness and deception standards and a violation of ECOA. ${ }^{238}$ Another possibility is accessing and or sharing consumer data without their consent, like the case about the flashlight app. ${ }^{239}$ Sharing consumer data that discloses sexual orientation or gender identity with or without notice could result in a UDAP or UDAAP violation and enforcement action from the FTC, CFPB, or both. ${ }^{240}$

\section{ii. UDAAP}

The FTC's guidance on the definitions of unfair and deceptive and the associated case law also apply to UDAAP under the CFPB. ${ }^{241}$ As to the abusiveness standard, CFPB has not created any regulations that further define "abusiveness." 242 The CFPB has recognized the challenge of creating a fully defined, exhaustive list of abusive acts or practices and recognized that if such a list were created, it could be easy to evade. ${ }^{243}$ As a result, the CFPB has provided guidance on what constitutes "abusiveness" on a case-by-case basis through its enforcement actions. ${ }^{244}$ Although the CFPB under Former Director Kraninger released guidance that attempted to define "abusiveness," the CFPB rescinded that guidance in 2021, under the leadership of Acting Director David Uejio, and announced a return to regulation by enforcement for UDAAP. ${ }^{245}$

One thing that is unclear from the policy change is whether the CFPB will return to the same decision process established under Cordray, or if Uejio, or a new director, will create new standards. The possibility of a new approach makes it hard to predict how discrimination based on sexual orientation or gender

237. See F.T.C. v. AMG Servs., Inc., No. 2:12-CV-00536-GMN, 2015 WL 4073192, at*1 (D. Nev. July 2, 2015); see also case cite supra note 227.

238. See 15 U.S.C. $§ 45$; see also supra notes 122-149 and accompanying text.

239. See sources cited supra notes 227, 228.

240. See In the Matter of Paypal, Inc., C-4651 (FTC 2018) (complaint); infra notes 241-248 and accompanying text.

241. See supra, notes 215-240 and accompanying text

242. CARNELL ET AL., supra note 85, at 551-52 (providing background on UDAP and UDAAP and CFPB's original practice of regulation by enforcement for UDAAP).

243. Id.

244. Id.

245. See Consumer Fin. Prot. Bureau, Statement of Policy Regarding Prohibition on Abusive Acts or Practices 1, 15 (2020) [hereinafter CFPB Abusiveness Framework Announcement], https://files.consumerfinance.gov/f/documents/cfpb_abusiveness-enforcementpolicy_statement.pdf (providing CFPB's framework and standards for the definition of "abusiveness" under Kraninger and the reasoning for the definition); Consumer Financial Protection Bureau Rescinds Abusiveness Policy Statement to Better Protect Consumers, Consumer Fin. Prot. Bureau (Mar. 11, 2021), https://www.consumerfinance.gov/about-us /newsroom/consumer-financial-protection-bureau-rescinds-abusiveness-policy-statement-tobetter-protect-consumers/; see CFPB ECOA Announcement, supra note 18 (documenting Uejio's status as CFPB's Acting Director). 
identity could put a financial institution at risk of enforcement action under UDAAP. ${ }^{246}$ However, it is possible that the CFPB could claim that discriminatory practices based on sexual orientation or gender identity that violate the unfairness or deceptive standards, like those discussed under UDAP, could also be abusive if the action was routine or pervasive. ${ }^{247}$ Additionally, regardless of whether the CFPB mirrors the FTC's posture on AIs and UDAP, CFPB may find a strategy that classifies AI discrimination as abusive under UDAAP. ${ }^{248}$

\section{H. State-Level Laws and Regulations Serving as a Resource and Inspiration}

Some financial institutions may have already dealt with liabilities arising from state-level laws that protect the LGBTQ+ community. ${ }^{249}$ Currently, twentythree states have laws that protect against discrimination in lending on the grounds of sexual orientation, and twenty states have laws that protect against gender identity discrimination. ${ }^{250}$ Listing and discussing every state-level law is beyond the scope of this article; instead, it suffices to say that financial institutions will have to consider another layer of regulations beyond the focus of this article.

Financial institutions that are subject to state laws will potentially have experience on how to adjust for complying at the federal level or will already be complying if there is not a difference between the state and federal requirements. Federal regulators may look to the state requirements that mirror the new federal requirements and mirror a state as a best practice or use a state's requirements as a springboard for creating the federal requirements. Additionally, financial institutions that are not subject to requirements at a state level could look at the various laws and compliance requirements at the state level to aid their efforts in planning the necessary actions to adapt to a federal level requirement.

\section{Ways That More CONCRETE Protection CAN BE CREATED}

\section{A. Why More Concrete Protection is Needed}

Without a change to the law that expressly prohibits discrimination against the LGBTQ+ community, the treatment of the community will continue to depend on the political administration and the interpretations of the political appointees

246. See generally CFPB Abusiveness Framework Announcement, supra note 245; CARNELL ET AL., supra note 85, at 551-52 (providing background on UDAP and UDAAP).

247. See supra notes 237-240 and accompanying text.

248. See supra notes 235-240 and accompanying text.

249. See First Nat. Bank v. Kentucky, 76 U.S. 353, 362 (1869) (finding national banks subject to state laws unless state law prevents discharging federal duties); Dillbary \& Edwards, supra note 8, at 22 (listing states prohibiting discrimination in lending based on sexual orientation and gender identity).

250. Dillbary \& Edwards, supra note 8, at 23 (listing states prohibiting lending discrimination based on sexual orientation and gender identity); LGBTQ+ HOUSING REPORT, supra note 69, at 23 (totaling states without protection). 
in charge of the relevant federal agency. ${ }^{251} \mathrm{LGTBQ}+$ protections are not just vulnerable in the area of financial services. ${ }^{252}$ For example, HUD proposed a rule change under the Trump administration that attempted to undo previous protections created under the Obama administration for transgender individuals. ${ }^{253}$ The Obama-era rule required homeless shelters to provide services to transgender individuals based on the gender that the individual identified as and prohibited shelters from refusing services just because the individual was transgender. ${ }^{254}$ However, just one day after Trump-appointed HUD Secretary Carson testified to Congress that he did not anticipate a change to the rule, HUD proposed a new rule that would roll back the Obama-era protections. ${ }^{255}$ Trump Attorney General Sessions also dismantled former Obama Attorney General Holder's guidance memo to the DOJ that stated sex discrimination included transgender status. ${ }^{256}$ The community's rights to healthcare, adoption, and education have also varied by presidential administration. ${ }^{257}$

While statutes can only be repealed by Congress or found unconstitutional by the Supreme Court, administrative agencies can generally change their own rules if they follow the Administrative Procedures Act (APA), and the new rules typically receive deference unless the agency's actions are demonstrably arbitrary and capricious. ${ }^{258}$ Some federal district courts have found that Trump administration rules that allowed discrimination against the LGBTQ+ community violated the APA, but there has not been a ruling from a Court of Appeals or

251. Hearing on Financial Services and the LGBTQ+ Community: A Review of Discrimination in Lending and Housing Before the H. Comm on Fin. Serv., 116th Cong. 7 (2019) [hereinafter David] (statement of Alphonso David, President, Human Rights Campaign) (stating need for Equality Act to amend Fair Housing Act of 1968 to add "sexual orientation and gender identity to list of protected characteristics"); Tobin, supra note 47, at 10-15; see CFPB SAGE Letter, supra note 13; Hilary J. Allen, The Pathologies of Banking Business as Usual, 17 U. PA. J. BuS. L. 861, 863-64 (2015) [hereinafter Allen Business as Usual] (stating criminal law and private litigation are not effective to address financial industry's negative behavior); Mishkin, supra note 113.

252. See generally Tobin, supra note 47, at 14 (discussing HUD's Equal Access rule changes impacting housing); Holder Memo, supra note 13; Sessions Memo, supra note 13.

253. See sources cited supra note 252 .

254. See sources cited supra note 252.

255. Tobin, supra note 47, at 14.

256. See Holder Memo, supra note 13; Sessions Memo, supra note 13.

257. Katie Keith, Third Court Rules Against Provider Conscience Rule, Health AfFs. (Nov. 20, 2019), https://www.healthaffairs.org/do/10.1377/hblog20191120.14018/full/; see, e.g.,Andrew Kreighbaum, Transgender Protections Withdrawn, INSIDE HiGHER ED (Feb, 23 2017, 3:00AM), https://www.insidehighered.com/news/2017/02/23/trump-administration-reverses-title-ix-guidancetransgender-protections; Julie Moreau, Trump Admin's Adoption Waiver 'Intentional Harms' Gays, Report Says, NBC NEws (Aug. 22, 2020, 4:30AM), https://www.nbcnews.com/feature/nbc-out/trumpadmin-s-adoption-waiver-intentionally-harms-gays-report-says-n1237631; Trudy Ring, Trump Admin's 'License to Discriminate' Health Care Rule Struck Down, The AdvocATE (Nov. 06, 2019), https:// www.advocate.com/health/2019/11/06/trump-admins-license-discriminate-health-care-rule-struck-down.

258. 5 U.S.C. $\$ 706(2)(a)$; Chevron, U.S.A. Inc, v. Nat. Res. Def Council, Inc., 467 U.S. 837, 865 (1984) (stating when a court reviews a challenge to federal agency's interpretation of a statute within the agency's oversight, the court must see if statute is ambiguous on the issue and if so, any reasonable interpretation from the agency will stand); see infra Part IV Section b. 
Supreme Court ruling on the issue. Informal guidance, including informal interpretive rules, is even easier to change, as was illustrated by the changes made under the Trump administration to the DOJ's guidance memos on the meaning of "based on sex," and also by the CFPB's short-lived "abusiveness" framework which was abandoned by the Biden administration. ${ }^{259}$

More concrete and explicit protections barring discrimination against the LGBTQ+ community in the provision of financial services can be created by promulgating new formal rules and regulations, passing the Equality Act, by enacting separate legislation specific to fair lending like Representative Al Green's (D-TX) Fair Lending Act for All, by ratifying the Equality Amendment to the U.S. Constitution, or by attempting a state-level solution. ${ }^{260}$ This Part will consider these approaches as possible improvements to the status quo that can succeed individually, or combined in a complementary manner.

\section{B. Administrative Law}

Before CFPB issued the ECOA interpretive rule, it was legal for a financial institution to deny an applicant's credit application or charge higher rates because the applicant(s) were LGBTQ+, as indicated by the three studies discussed in the HMDA section. ${ }^{261}$ The new interpretive rule is a welcome policy change, but implementing an informal interpretive rule provides the lowest level of protection in administrative law because interpretive rules are easily rescinded. ${ }^{262} \mathrm{~A}$ new administration merely has to state that it is reading the applicable statute differently to justify rescinding an interpretive rule. ${ }^{263}$ Thus, to create a more concrete level of protection via administrative law, a rule must be promulgated

259. Id.; Keith, supra note 257; Ring, supra note 257; see supra notes 245-248 and accompanying text.

260. See sources cited supra note 249; see David, supra note 251; see Laura Eckert, Inclusion of Sexual Orientation Discrimination in the Equal Credit Opportunity Act, 103 COM. L.J. 311, 334 (1998).

261. See Dillbary \& Edwards, supra note 8, at 3, 9 (2019) (stating most federal laws do not prohibit discrimination in lending based on sexual orientation); Sun \& Gao, supra note 8 (stating no requirement to disclose sexual orientation); see also Cyrus Mostaghim, The True Colors of Financial Services and LGBTQ+ Discrimination, AM. U. Bus. L. REV.: ThE BLR BuZz Blog (Nov. 16, 2019) [hereinafter Mostaghim LGBTQ+ Discrimination], http://www.aublr.org/2019/11/the-true-colors-offinancial-services-and-lgbtq-discrimination/ (serving as author's initial exploration on topic, providing additional background information and risk of discrimination against LGBTQ+ community in fintech AIs).

262. See Am. Hosp. Ass'n v. Bowen, 834 F.2d 1037, 1045 (D.C. Cir. 1987) (discussing section 553 of the Administrative Procedures Act's exemptions for interpretive rules and general policy statements); see generally Pac. Gas \& Elec. Co. v. Fed. Power Comm'n, 506 F.2d 33, 37-38 (D.C. Cir. 1974) (discussing difference between interpretive and substantive rules).

263. See Andrew F. Popper et Al., Administrative Law: A CONTEMPORARy Approach 282-83, (3d. ed. 2016) (illustrating the distinction between interpretive rules and substantive rules via discussion of Pac. Gas \& Elec. Co. v. Fed. Power Comm'n, 506 F. 2d 33 (D.C. Cir. 1947), Nat'l Org. of Veterans' Advocates v. Sec'y of Veterans Affairs, 260 F.3d 1365 (Fed. Cir. 2001), and views of various legal scholars). 
through one of the processes that give administrative rules the force of the law, such as formal rulemaking, notice and comment, or negotiated rulemaking. ${ }^{264}$

To rescind a rule that has the force of the law, an agency must "publish a 'concise and general' statement of basis and purpose." 265 The reasoning asserted for the agency's decision must also have a rational connection to the facts cited as support for the agency's justification. ${ }^{266}$ Should the reasons asserted fail to pass judicial review, the reviewing court will deem the action to be arbitrary and capricious and reverse the agency's action. ${ }^{267}$

While the recission of formal rules is possible (albeit more difficult than rescinding an interpretive rule), rulemaking allows an agency to address an issue within the agency's jurisdiction and avoid the partisan gridlock in Congress. ${ }^{268}$ To be clear, the creation of a more concrete level of protection for the LGBTQ+ community via formal rulemaking cannot be achieved through any one single rule. While ECOA makes discrimination against protected classes in access to credit illegal, the law is just one of the financial regulation statutes that cover consumer finance, and the law does not provide all the necessary tools for regulators to identify discrimination. ${ }^{269}$ Protection without the ability to identify issues via supervision and examination of banks leaves the CFPB, other regulatory agencies, and consumer advocate groups only able to act on an individual consumer's complaint. ${ }^{270}$ In short, multiple statutes will require multiple formal rulemakings to implement protections for the LGBTQ+ community. ${ }^{271}$

Despite the preference for formal rulemakings, more informal regulatory approaches do have some positive aspects. The first aspect is that an agency can issue a clarification on an interpretive rule via a policy statement that gives

264. See id.; id. at $72-174,610-27$ (discussing various forms of rulemaking and their requirements, if force of the law applies for a rule issued under each process, and providing additional guidance and requirements via excepts of applicable case law); Am. Hosp. Ass'n v. Bowen, 834 F.2d 1037, 1045 (D.C. Cir. 1987) (discussing section 553 of the Administrative Procedures Act's exemptions for interpretive rules and general policy statements); Pac. Gas \& Elec. Co. v. Fed. Power Comm'n, 506 F.2d 33, 37-38 (D.C. Cir. 1974) (discussing difference between interpretive and substantive rules).

265. See Motor Vehicle Mfrs. Ass'n of U.S., Inc. v. State Farm Mut. Auto. Ins. Co., 463 U.S. 29 (defining the requirements and standard for judicial review of an agency's action of rescinding a rule); POPPER ET AL., supra note 263, at 149 (discussing how State Farm, 463 U.S. 29, (1983), and section 553(c) of the APA creates a requirement for rescinding rules).

266. See sources cited supra note 265 .

267. See sources cited supra note 265 .

268. See supra notes 265-267 and accompanying text; POPPER ET AL., supra note 263, at 505 (discussing scope of administrative agency power).

269. See id.; see generally Kennedy et al., supra note 109 (providing overview of the CFPB's mission and an overview of the laws that CFPB has jurisdiction to enforce).

270. See 2012 Equal Access Rule, supra note 182, at 5663, 5669-70 (addressing public comments on the lack of data to identify discrimination against the LBTQ+ community in housing and urging HUD to create a database to help identify discrimination against the community).

271. Id. 
guidance on what is permissible under the rule. ${ }^{272}$ As long as the guidance is within the scope of the promulgating agency's expertise, the guidance will receive some deference from the courts. ${ }^{273}$ Second, an informal interpretive rule does not preclude an administrative agency from pursuing additional formal rulemaking. ${ }^{274}$ As Judge Wald stated in the opinion for American Hospital Association v. Bowen, ${ }^{275}$ "The function of the second $\S 553$ exemption, for "general policy statements," is to allow agencies to announce their "tentative intentions for the future." 276 Thus, an administrative agency can use an informal interpretive rule to serve as notice to the public and financial institutions about the agency's intentions for future actions, including promulgating more formal rules. ${ }^{277}$ A more formal rule promulgated based on an informal interpretive rule will remain in force even if the informal interpretive rule is rescinded at some point in the future. ${ }^{278}$ However, no amount of rules (formal or informal) can force the political leadership of an agency to actively enforce regulations.

Enforcement may become less likely as a result of CFPB's final rule on supervisory guidance that was issued in February of 2021. ${ }^{279}$ Essentially, the rule states that CFPB will not pursue enforcement actions based on violations of supervisory guidance and that CFPB examiners generally may not "criticize (including through the issuance of matters requiring attention, matters requiring immediate attention, matters requiring board attention, documents of resolution, and supervisory recommendations) a supervised financial institution for, and agencies will not issue an enforcement action on the basis of, a "violation" of or "non-compliance" with supervisory guidance." 280 The discussion in the final rule's documentation highlights the similarities and differences between

272. See Auer v. Robbins, 519 U.S. 452, 461 (1997) (holding that judicial review for the interpretation of a regulation should give deference to the regulation's promulgator "unless 'plainly erroneous or inconsistent with the regulation"'); Kisor v. Wilkie, 139 S. Ct. 2400, 2424 (2019) (holding Auer deference does not apply when the regulation or interpretation is out of the scope of the agency's expertise); POPPER ET AL., supra note 263, at 203-05 (explaining and clarifying Auer deference).

273. Id.

274. See Am. Hosp. Ass'n v. Bowen, 834 F.2d 1037, 1045 (D.C. Cir. 1987) (discussing section 553 of the Administrative Procedures Act's exemptions for interpretive rules and general policy statement).

275. 834 F.2d 1037 (D.C. Cir. 1987).

276. Id. at 1046 (emphasis added).

277. See id. at 1046.

278. Id.

279. See Role of Supervisory Guidance, 86. Fed. Reg. 9261, 9262, 9265 (Feb. 21, 2021) (stating CFPB will not pursue enforcement actions based on violations of supervisory guidance and CFPB examiners may not "criticize (including through the issuance of matters requiring attention, matters requiring immediate attention, matters requiring board attention, documents of resolution, and supervisory recommendations) a supervised financial institution for, and agencies will not issue an enforcement action on the basis of, a "violation" of or "non-compliance" with supervisory guidance.").

280. Id 
supervisory guidance and interpretive rules, and explicitly says that interpretive rules can be enforced although supervisory guidance cannot. ${ }^{281}$

This suggests that enforcement of CFPB's ECOA interpretive rule (or a future final rule with the force of the law) will not be directly impacted, but there is the potential for the rule on supervisory guidance to frustrate enforcement of any supervisory guidance needed to flesh out the interpretive rule or any other future rules for the other consumer protection statues that address the LGBTQ+ community. ${ }^{282}$ An example would be the scenarios of harassing behavior, hate speech and threats to out an individual, in the Fair Debt Collection Practices Act discussion. ${ }^{283}$ It may be possible to frame the use of hate language specific to the community or threatening to out an individual as a direct violation of the statute using the traditional "but-for" argument for sex-based discrimination, ${ }^{284}$ but it would be far easier to issue supervisory guidance that states these actions are examples of LGBTQ+ discrimination. ${ }^{285}$

The potential for the rule to frustrate actions under the ECOA interpretive rule, a future final rule, or new rules for the other consumer protection statutes that require the creation of supervisory guidance to address concerns unique to the LGBTQ+ community illustrates the desirability of a more concrete and permanent legal foundation for preventing discrimination against the community.

\section{Classifying the LGBTQ+ Community as a Quasi-Suspect Class}

Notwithstanding the agility of formal and informal rulemaking, more durable protection is desirable, and it could be provided by the courts. If a court were to apply the Cleburne factors to the LGBTQ+ community, strong arguments could be made that the LGBTQ+ community is a quasi-suspect class entitled to a

281. Id. at 9265 .

282. See id. at 9262; sources cited supra note 18.

283. See supra text accompanying notes 208-210.

284. While sex-based discrimination case-law technically only applies to the associated statute, such as Title VII for employment, courts and regulators tend to follow case law from other statutes that is analogous with the type of behavior at issue and regulators tend to mimic case law from other statutes in regulations that cover the same subject. See Faragher v. City of Boca Raton, 524 U.S. 775, 778-79 (1998) (establishing reasonable care standard for employers to avoid liability for indifference under Title VII (employment)); Davis v. Monroe Cty. Bd. of Educ., 526 U.S. 629, 630 (1999) (holding liability for indifference to sexual harassment is possible under Title IX (education)); Quid Pro Quo and Hostile Environment Harassment and Liability for Discriminatory Housing Practices under the Fair Housing Act, 81 Fed. Reg. 63054 (Sept. 14, 2016) (codified at 24 C.F.R. Pt. 100) (defining quid pro quo and hostile environment sexual harassment under Title VIII (Fair Housing Act, 42 U.S.C. $\S$ 3601 et seq.)); Policy Guidance on Employer Liability under Title VII for Sexual Favoritism, EEOC, https://www.eeoc.gov/laws/guidance/policy-guidance-employer-liability-under-title-vii-sexualfavoritism (last visited July 1, 2021) (stating EEOC quid pro quo and hostile environment sexual harassment definition under Title VII).

285. Bostock v. Clayton Cnty., 140 S. Ct. 1731, 1739-41 (2020) (discussing "but-for" standard for Title VII). 
heightened level of scrutiny for constitutional challenges and inclusion in antidiscrimination and civil rights statutes. ${ }^{286}$

For the first Cleburne factor (relating to the severity and pervasiveness of discrimination), the LGBTQ + community has faced discrimination and persecution since before the founding of this country (when it was illegal to be gay). ${ }^{287}$ After women gained the right to vote, the full LGBTQ+ community had the right to vote, but the community still faced limitations on its access to political power. ${ }^{288}$ Although there was some activism from the community, the visibility of the community was limited in many ways. ${ }^{289}$ Part of the issue was that most LGBTQ+ individuals were still closeted due to fear of loss of employment, particularly during and after the Lavender Scare, a period of time where the federal government actively sought and purged LGBTQ+ employees from federal employment. ${ }^{290}$ As the LGBTQ+ community gained more visibility via the media, events like the Stonewall riots and Pride parades, political figures like Harvey Milk, the creation of advocacy groups like the National Gay \& Lesbian Task Force, the Human Rights Campaign (HRC), Lambda Legal, and GLBTQ Legal Advocates \& Defenders (GLAD), and more individuals came out (some inspired by the many queer anthems ${ }^{291}$ ) and showed their "True Colors" to friends

286. City of Cleburne, Tex. v. Cleburne Living Ctr., Inc., 473 U.S. 432 (1985); see also Romer v. Evans, 517 U.S. 620, 635-36 (1996) (finding state constitution amendment barring and undoing local LGBTQ+ antidiscrimination laws unconstitutional); Bowers v. Hardwick, 478 U.S. 186, 196 (1986) (finding no right to sexual privacy for LGBTQ+ community), overruled by Lawrence $v$. Texas, 539 U.S. 558 (2003); GSAFE LGBTQ+ Timeline, supra note 48; PBS LGBTQ+ Timeline, supra note 48; Fair Educ. LGBTQ + Timeline, supra note 48; see sources cited supra note 286.

287. See Obergefell v. Hodges, 576 U.S. 644, 681 (2015) (finding right to marriage for LGBTQ+ community); see also United States v. Windsor, 570 U.S. 744, 774-75 (2013) (finding Defense of Marriage Act's restrictions on LGBTQ+ community unconstitutional); Lawrence v. Texas, 539 U.S. 558, 578-79 (2003) (finding right to sexual privacy for LGBTQ+ community); Romer, 517 U.S. 620, 635-36 (finding unconstitutional state constitution amendment barring and undoing local antidiscrimination laws against LGBTQ+ individuals); Bowers, 478 U.S. 186 (finding no right to sexual privacy for LGBTQ+ community), overruled by Lawrence, 539 U.S. 558; GSAFE LGBTQ+ Timeline, supra note 48; PBS LGBTQ+ Timeline, supra note 48; Fair Educ. LGBTQ+ Timeline, supra note 48 .

288. See Bowers, 478 U.S. 186 (1986) (finding no right to sexual privacy for LGBTQ+ community), overruled by Lawrence, 539 U.S. 558; GSAFE LGBTQ+ Timeline, supra note 48; PBS LGBTQ+ Timeline, supra note 48; Fair Educ. LGBTQ+ Timeline, supra note 48; ACLU History: Earliest Advocacy on Behalf of LGBT People, AM. C. L. UNION (Sept. 1, 2010), https://www.aclu.org /other/aclu-history-earliest-advocacy-behalf-lgbt-people; About Us, HUM. RTS. CAMPAIGN., https://www.hrc.org/hrc-story/about-us (last visited Mar. 19, 2020).

289. See GSAFE LGBTQ + Timeline, supra note 48; PBS LGBTQ+ Timeline, supra note 48; Fair Educ. LGBTQ+ Timeline, supra note 48. See generally ERIC CERVINI, THE DEVIANT's WAR: THE HoMOSEXUAL vs. THE UNITED STATES OF AMERICA (2020) (providing historical information on the LGBTQ+ community's efforts to lobby for change in the law related to the community).

290. See sources cited supra note 289.

291. Lyrics to queer anthems are commonly about survival, acceptance, self-love, or unrequited love. Examples include Somewhere Over the Rainbow, I Will Survive, I'm Coming Out, Beautiful, Born This Way, and titles used in TripAdvisor's Cease and Desist letter to organizers of the 2019 Boston Straight Pride Parade attempt. Judy Garland, SOMEwhere Over THE RAINBow (MGM Records 1956); Gloria GaYNor, I Will SuRvive (Polydor Records 1978); Diana Ross, I'M 
and family (increasing the number of people who "knew someone") the community's ability to effect political change increased. ${ }^{292}$

For the first part of the third prong, the LGBTQ+ community does have immutable characteristics for sexual orientation and gender identity. ${ }^{293}$ Although science has not determined what factors determine sexual orientation or gender identity, people generally agree that it is not an active choice that can be changed. ${ }^{294}$ While some may argue that being transgender is not an immutable trait because an individual's sex changes with a transition surgery, the reasoning is flawed. ${ }^{295}$ There is a difference between sex and gender, where sex deals with the body's primary and secondary sex characteristics and gender is an immutable trait ${ }^{296}$ of one's own perception. ${ }^{297}$ Moreover, it is inappropriate to use the

Coming Out (Motown 1980); Christina Aguilera, Beautiful (RCA 2002); LAdy GAGA, Born THIS WAY (Interscope Records 2011) (serving as an LGBTQ+ anthem stating "I'm beautiful in my way 'cause God makes no mistakes, I'm on the right track, baby I was born this way...no matter gay, straight, or bi, lesbian, transgendered life, I'm on the right track baby, I was born to survive"); Callum Borchers, Here's Every Gay Anthem Reference in TripAdvisor's Letter to the 'Straight Pride Parade' Organizers, WBUR NEWS (July 24, 2019), https://www.wbur.org/news/2019/07/23/boston-straightpride-corporate-sponsor-cease-and-desist (describing why each song title in TripAdvisor's Cease and Desist Letter is a gay anthem).

292. Cynd LAUPER, TRUe COlORS (Epic Records 1986); see sources cited supra note 289; Molly Ball, How Gay Marriage Became a Constitutional Right, ThE AtLantic (July 1, 2015), https://www.theatlantic.com/politics/archive/2015/07/gay-marriage-supreme-court-politics-activism /397052/ (discussing tactics used to convince general public of the "normalcy" of the gay community and how "old-lady lesbians... were the best messengers").

293. See Jeffrey Kluger, No Ben Carson, Homosexuality is Not a Choice, TIME, https://time.com/3733480/ben-carson-gay-choice-science/ (last visited Mar. 19, 2020) (discussing possibilities of homosexuality's cause and refuting incorrect theories); Answers to your Questions About Transgender People, Gender Identity and Gender Expression, AM. PSYCH. Ass'N [hereinafter APA Transgender], https://www.apa.org/topics/lgbt/transgender (last visited Mar. 19, 2020) (providing background on transgender community and gender identity and expression); Answers to Your Questions For a Better Understanding of Sexual Orientation and Homosexuality, АM. РSYCH. Ass'N [hereinafter APA Sexual Orientation], https://www.apa.org/topics/lgbt/orientation (last visited Mar. 19, 2020) (illuminating background information on sexual orientation and answering frequently asked questions).

294. See Kluger, supra note 293; APA Transgender, supra note 293; APA Sexual Orientation, supra note 293.

295. See KC Clements, What's the Difference Between Sex and Gender?, HEALTHLINE, https://www.healthline.com/health/sex-vs-gender\#is-there-a-connection? (last visited. Mar. 19, 2020) (proposing "gender is in the brain and sex is in the pants") (quotations omitted); Kluger, supra note 293.

296. "The term "immutable trait" is used within the constitutional context to describes a trait that is beyond the power of the individual to change, trans and gender-nonconforming identities are immutable in that they exist and cannot be changed, however, the LGBTQ+ community recognizes that gender is a fluid spectrum that can and does change through a person's life." Email from Chris Marin, Vol. 73 Admin. L. Rev. Note \& Comment Ed., to Cyrus Mostaghim, Author (July 24, 2021, 1:18 PM) [hereinafter Marin] (on file with author); see Telephone Interview with Dana Savage, President Elect- QLaw Ass'n of Wash. and co-drafter of Wash. State SB 5313 (Gender Affirming Treatment Act) (July 25, 2021) [hereinafter Savage] (providing insight on the transgender community view regarding immutable traits).

297. See Marin, supra note 296; Savage, supra note 296. 
changes a trans or gender non-conforming person makes to their physical sex characteristics as a means of arguing against the immutability of their gender identity. ${ }^{298}$ The physical changes to the individual's sex characteristics do not create a new identity; they are an act of confirming and making seen the identity that already exists (because they were "Born This Way") within their own experienced sense of self. ${ }^{299}$ It must also be noted that "trans or gender nonconforming individuals exist naturally and" it is an inappropriate measure of their immutability to look to a person's changes to their physical sex characteristics to help align with their gender identity as the changes are already confirming an immutable identity that is already there. ${ }^{300}$ Finally, for the second part of the third prong, the LGBTQ+ community has kept to itself throughout history for safety reasons. ${ }^{301}$ While there has been progress in acceptance since the legalization of gay marriage, the community continues to face public and private animus from intolerant groups and still has tendencies to keep to itself. ${ }^{302}$

The Bostock decision could be invoked to bolster this Cleburne analysis. While the Bostock decision was about statutory protections under Title VII, the Supreme Court's holding implicitly acknowledges that the LGBQ+ community experiences discrimination. ${ }^{303}$ Thus, a future case could cite Bostock as persuasive and argue that the community's need for statutory protection against discrimination under Title VII reflects a need for more comprehensive protection via designation as a quasi-suspect class. ${ }^{304}$ However, the Court's history of providing the LGBTQ+ community new rights in piece-meal fashion suggests that it will be unlikely to adopt a blanket quasi-suspect class designation for the community. ${ }^{305}$ The change in the Court's composition after the death of Justice Ginsburg also makes such an outcome less likely. ${ }^{306}$ Additionally, the Court's new composition also calls into question whether the application of the arguments and legal analysis from Bostock to a case that involved a financial regulation statute, such as ECOA, would conclude that discrimination based on sexual

298. See id.

299. LADY GAGA, supra note 291; see Marin, supra note 296; Savage, supra note 296.

300. See Marin, supra note 296; Savage, supra note 296.

301. See e.g., Perry, N. Halkitis, Discrimination and Homophobia Fuel the HIV Epidemic in Gay and Bisexual Men, AM. PSYCH. Ass'N (April 2012), https://www.apa.org/pi/aids/resources /exchange/2012/04/discrimination-homophobia.

302. See id.

303. See Bostock v. Clayton Cnty., 140 S. Ct. 1731, 1737 (2020).

304. See generally Devah Pager \& Hana Shepard, The Sociology of Discrimination: Racial Discrimination in Employment, Housing, Credit, and Consumer Markets, 34 ANNU. REV. SocIO. 181 (2008) (discussing discrimination against the African American community in the areas of "employment, housing, credit markets, and consumer interactions").

305. See supra notes 48-59 and accompanying text.

306. Justice Ruth Bader Ginsburg Passes, Justice Amy Coney Barret Seated as Replacement, ABA (Jan. 25, 2021), https://www.americanbar.org/groups/committees/death_penalty_representation/project _press/2020/year-end-2020/amy-coney-barrett-replaces-ginsburg-on-supreme-court/ (discussing Justice Barrett's replacement of Justice Ginsburg and Barrett's difference in ideology). 
orientation and/or gender identity is a form of sex discrimination. However, if reached, a favorable court decision would create more durable prohibitions on financial discrimination against the LGBTQ + community. ${ }^{307}$ Additional regulatory action (such as changes to HMDA data points) would then be needed to provide the necessary tools for regulators to identify that discrimination. ${ }^{308}$

\section{Congressional Action and New Legislation}

Currently, two pieces of legislation are under consideration that could create more concrete statutory protections: the Equality Act and Representative Al Green's (D-TX) Fair Lending Act for All. ${ }^{309}$ The Equality Act is comprehensive legislation that amends the Civil Rights Act of 1964, ECOA, and other statutes and regulations to include sexual orientation and gender identity under sex discrimination. ${ }^{310}$ Representative Green's Fair Lending Act for All focuses on amending fair lending statutes and regulations to include sexual orientation and gender identity. ${ }^{311}$ Both would provide important and durable protections for the LGBTQ+ community, but the likelihood of passage is still in question as the House of Representatives has passed the Equality Act during multiple sessions while the Senate has not voted on the act (and currently appears to lack support to overcome the $50 / 50$ split by party-line vote). ${ }^{312}$

\section{E. The Equality Amendment to the Constitution}

A constitutional amendment could provide general protection to the LGBTQ + community, and while unlikely, it might not be impossible. ${ }^{313}$ Virginia's ratification of the Equal Rights Amendment in 2020 was the last one needed to achieve the required number of states for the amendment's

307. See supra notes 269-271 and accompanying text.

308. See supra notes 269-271 and accompanying text.

309. The Equality Act, H.R. 5, 116th Cong. (2019) (amending the Civil Rights Act of 1964); Fair Lending Act for All, H.R. 166, 116th Cong. (2019).

310. See H.R. 5, $116^{\text {th }}$ Cong., $\S \S 6-10$ (2019).

311. See H.R. 166, $166^{\text {th }}$ Cong., $\S \S 3-6$ (2019).

312. Tyler Deaton, How to Pass the Equality Act in a Tied Senate, THE HiLl (Feb. 26,2021), https://thehill.com/changing-america/opinion/540692-how-to-pass-the-equality-act-in-a-tied-senate (discussing challenges of passing the Equality Act in the Senate's 50/50 split by political party); Sarah McBride, Historic: U.S. House of Representatives Passes the Equality Act, HuM. RTs. CAMPAIGN (May 17, 2019), https://www.hrc.org/news/historic-house-of-representatives-passes-the-equality-act (documenting prior passage of Equality Act in the House).

313. See Joseph Guzman, Virginia Finalizes its passage of the Equal Rights Amendment, THE HILL (Jan. 27，2020), https://thehill.com/changing-america/respect/equality/480172-virginia-ratifies-equalrights-amendment (discussing Virginia being final state ratifying Amendment and resulting legal and constitutional questions on passage timeline); Tom Spiggle, Did Virginia Just Make The Equal Rights Amendment part of the Constitution?, FORBES (Feb. 7, 2020), https://www.forbes.com/sites/tomspiggle /2020/02/07/did-virginia-just-make-the-equal-rights-amendment-part-of-the-constitution/\#21611023393c (providing Equal Rights Amendment background and legal issues from approval timeline). 
ratification. ${ }^{314}$ However, since the ratification occurred after the 1979 deadline, the status of the amendment is unclear (the issue is further complicated by the fact that some states that ratified the amendment want to withdraw their ratification). ${ }^{315}$

Should the Equal Rights Amendment become effective, it could be helpful to the LGBTQ+ community, but the amendment would have the same issue as Title VII; the text does not explicitly mention sexual orientation and gender identity. ${ }^{316}$ Unlike Title VII, there is not an "EEOC" for constitutional amendments that can provide clarification and guidance; interpretation lies with the Supreme Court. ${ }^{317}$ Thus, even if the other constitutional and legal issues with the Equal Rights Amendment were resolved, the Court would have to decide a case under the Equal Rights Amendment that adopts the logic in Bostock before sexual orientation and gender identity were constitutionally protected by the word "sex." 318

\section{F. State-Level Action}

Although federal protection would be the most comprehensive, it seems unlikely that this will be achieved in the near term. States sometimes step into the breach when there is federal inaction. However, while states may adopt more restrictive requirements for financial institutions operating within their borders, they run the risk of preemption by federal law. ${ }^{319}$ Additionally, unless all states pass similar legislation, the LGBTQ+ community will have a mere patchwork of protection. The experience of states allowing same-sex marriage is instructive here. ${ }^{320}$ Before the Obergefell case established federal same-sex marriage, only nineteen states allowed same-sex marriage. ${ }^{321}$ Thus, it seems unlikely that state legislatures will provide a comprehensive solution. ${ }^{322}$ Even if state legislation is enacted (just as if a federal law is enacted by Congress or a formal rule is adopted by a regulatory agency), it will only provide durable protection to the LGBTQ+ community if it can survive the associated judicial review process. ${ }^{323}$

\footnotetext{
314. See Guzman, supra note 313.

315. Id.; see Spiggle, supra note 313.

316. See H.R.J. Res. 75, 68th Cong. (1923).

317. See U.S. CONST. art. III, §§ 1-2 (establishing and defining SCOTUS's judicial power, stating other courts are inferior, and binding all courts to follow SCOTUS precedent); Marbury $v$. Madison, 5 U.S. 137, 146 (1803) (stating Supreme Court is final court and superior to all other courts).

318. Bostock v. Clayton Cnty., 140 S. Ct. 1731, 1737 (2020).

319. See U.S. ConsT. art. VI, cl. 2; First Nat'l Bank v. Kentucky, 76 U.S. 353, 362 (1869) (finding national banks subject to state laws unless state law prevents bank from discharging federal duties).

320. See generally A Brief History of Civil Rights in the United States: A Timeline of the Legalization of Same-Sex Marriage in the U.S., Geo. LAW LiBR., (Aug. 26, 2021, 8:08AM) [hereinafter Gay Marriage Timeline], https://guides.ll.georgetown.edu/c.php?g=592919\&p=4182201.

321. Obergefell v. Hodges, 576 U.S. 644, 681 (2015) (establishing LGBTQ+ community's marriage rights); see Gay Marriage Timeline, supra note 320.

322. See generally Gay Marriage Timeline, supra note 320.

323. See sources cited supra note 113.
} 


\section{Potential IMPACTS OF REGULATORY CHANGES}

No attempt to create protection for the LGBTQ+ community from discrimination in access to financial services is guaranteed to be permanent. However, a complementary mix of more durable protections can significantly improve the situation for the community. If more concrete protections for the LGBTQ + community are adopted, the CFPB may need to make new rules and offer guidance to address new scenarios specific to discrimination against LGBTQ+ individuals. ${ }^{324}$ In doing so, the CFPB must be mindful of overlapping statutes. Naturally, anytime that new statutory or regulatory requirements are created, a regulated entity will incur some costs associated with adopting the new requirements.

\section{A. Costs of Complying with New Regulatory Changes}

The impact of the CFPB's informal rule interpreting ECOA as covering sexual orientation and gender identity may result in new requirements for data collection, compliance procedures, financial institutions' Standard Operating Procedures for approving credit applications, any associated documentation requirements, and regulatory procedures for examination of financial institutions. ${ }^{325}$ Financial institutions may experience an increase in operational costs as a result, and failure to properly implement new requirements may result in compliance penalties, enforcement actions, or other legal liability. ${ }^{326}$ Compliance costs will also increase with any future updates to any of the financial regulation statutes or regulations. Financial institutions could also lose business from the LGBTQ+ community if discriminatory practices come to light as a result of the new protections for the community. ${ }^{327}$ However, as our society continues to grapple with issues of diversity, equity, and inclusion across all aspects of life, a marginal increase in operating costs to ensure fairness and equity in access to credit is easily justified. ${ }^{328}$

324. See ChEMERINSKY, supra note 31, at 342 (discussing powers of federal regulatory agencies).

325. See Hilary J. Allen, A New Philosophy for Financial Stability Regulation, 45 LOY. U. CHI. L.J. 173, 185, 190-91 (2013) [hereinafter Allen FS Philosophy] (discussing cost impact of financial regulation and how cost-benefit analysis is sometimes used to determine value of regulation); John C. Coates IV, Cost-Benefit Analysis of Financial Regulation: Case Studies and Implications, 124 YALE L.J. 882, 998-99 (2015) [hereinafter CBA \& Fin. Reg.] (asserting cost-benefit-analysis of financial regulation cannot be done accurately and not a good basis for policy setting).

326. See id.

327. See Karma Allen, supra note 78; John Schneider \& David Auten, The \$1 Trillion Marketing Executives are Ignoring, FORBES (Aug. 14, 2018), https://www.forbes.com/sites /debtfreeguys/2018/08/14/the-1-trillion-marketing-executives-are-ignoring; Umoh, supra note 77; Nick Wolny, The LGBTQ + Community has $\$ 3.7$ Trillion in Purchasing Power; Here's How We Want You to Sell to Us, ENTREPRENEUR (June 10, 2019), https://www.entrepreneur.com/article/334983.

328. See id.; Jordan Bryan, How 2020 Accelerated Conversations on Diversity, Equity, and Inclusion, GARTNER: SMARTER WITH GARTNER (Feb. 3, 2021), https:/www.gartner.com/smarterwithgartner/how- 


\section{B. Increased Complexity in Supervision, Enforcement, and Compliance}

Financial regulators already face a large amount of difficulty and complexity in the supervision and examination function of financial institutions. The addition of sexual orientation and gender identity to the list of protected statuses raises specific issues where victims are members of multiple protected classes. A victim may need to identify which protected class was the reason for the discrimination, and regulators may need to update their internal guidance and procedures to address scenarios that involve overlapping protected statuses. A regulator's job will also be more complex if an issue implicates multiple statutes or regulations or falls under the jurisdiction of multiple regulators at the federal, state, or local level.

In addition to reviewing customer complaints, regulators can discover discrimination through two different methods. ${ }^{329}$ The first is during a regulator's examination activities. ${ }^{330}$ The second method is through an existing field test method using undercover shoppers sent by a regulator or advocate group. ${ }^{331}$ Currently, regulatory agencies and consumer advocate groups use undercover shoppers as an in-person test to identify potential discrimination. ${ }^{332}$ By sending in various combinations of couples (i.e., both white, both the same minority, any combination of white and minority, or two different minorities), an institution or advocacy group can gather real-time data to identify and prove discrimination on the basis of race. ${ }^{333}$

Regulators and consumer groups could expand their undercover shopper programs to test for sexual orientation or gender identity discrimination by sending in shoppers posing as various members of the LGBTQ+ community. However, the presence of multiple protected statuses in one test case would result in more difficulty with the identification of which status or statuses were the reason for discrimination. It is far easier to identify race discrimination within heterosexual pairings. For the LGBTQ+ community, additional steps may need to be taken to determine if the discrimination against a same-sex couple was because it was a male couple, female couple, same race couple of both gender pairings, or a mixed-race couple of both gender pairings. The same steps would also need to happen for a transgender paring, including one or both individuals being transgender. This need exponentially increases the number of tests that would be needed and the level of effort and complexity for identifying the reasons for the discrimination. Given the sensitivity of information about sexual orientation and gender identity, the CFPB must be particularly mindful of data

2020-accelerated-conversations-on-diversity-equity-and-inclusion/ (discussing how the events of 2020 have forced greater dialogue on diversity and equity issues than the \#MeToo movement in the employment arena).

329. See CARNELL, supra note 85 , at 344-45 (discussing purpose of federal regulator examining financial institutions); see Dillbary \& Edwards, supra note 8, at 30-32 (describing field tests).

330. See sources cited supra note 329.

331. See id.

332. See Dillbary \& Edwards, supra note 8, at 30-32 (describing field tests).

333. See id. 
privacy-related statutes so that it can have the data that it needs while protecting the privacy of consumers.

\section{Implications Related to Data Privacy Statutes}

The CFPB must identify a best practice for anonymizing sexual orientation and gender identity data while maintaining a way to identify individuals as necessary for enforcement actions (and if a law provides a private right of action, allowing the individual to locate their data). ${ }^{334}$ Anonymizing data is vital because sexual orientation and gender identity data points are sensitive subjects for individuals and collecting them could result in individuals being outed involuntarily. Also, because IT security breaches are becoming more common, CFPB must consider extra steps and requirements to protect its internal data to avoid accidental "outings."

Individuals who may be comfortable self-identifying when seeking financial services may not be entirely out in their personal or professional life. For example, consider a scenario where CFPB pursues enforcement action against a financial institution and lists consumers who self-identified but are not completely "out" in various trial documents. Unless a party designates a court document as a confidential record, court documents are open to the public. ${ }^{335}$ Thus, individuals listed in court documents could be outed to friends, family members, and employers or coworkers who read those documents or media reports based on them. ${ }^{336}$ Thanks to Bostock, these outed individuals will have employment protection under Title VII. ${ }^{337}$ However, there are no legal remedies for outing an individual to their friends and family, particularly if the outing results in a financial loss, such as disinheritance by family members. ${ }^{338}$

CFPB may be able to look at HUD's experience with the 2012 promulgation of the Equal Access Rule for guidance on how to handle this issue. ${ }^{339}$ When HUD proposed the rule, there were public comments lobbying for a database to house data to help identify individual instances or trends of discrimination and to monitor the rule's effectiveness in preventing discrimination. ${ }^{340}$ Additionally,

334. See Stephen P. Mulligan \& Chris D. Linebaugh, Cong. Rsch. Serv., Data Protection Law: An Overview 8-10, 12-14, 21-23, 25-36, 38-40 (2019) [hereinafter Data Protection Law] (providing an overview of data protection statutes and potential requirements for data financial institutions store or transmit).

335. Court Records and Proceedings: What is Public and Why?, CONNOR RePORTING, https://connorreporting.com/court-records-proceedings-public/ (last visited Apr. 18, 2021).

336. See id.; Mathieu J. Shapiro, When Is a conflict Really a Conflict? Outing and the Law, 36 B.C. L. REV. 587, 588 (1995) (stating First Amendment protections often preclude a claim against the media for a breach of privacy).

337. Bostock v. Clayton Cnty., 140 S. Ct. 1731, 1737 (2020).

338. Scott Skinner-Thompson, Outing Privacy, 110 Nw. L. REV. 159, 200 (2015) (asserting that courts have "routinely invoke[d] qualified immunity to defeat informational privacy claims" against the government); Shapiro, supra note 336; CONNOR REPORTING, supra note 335.

339. See source cited supra note 270.

340. See id. 
there were also comments about the LGBTQ+ community's unique privacy concerns regarding sexual orientation and gender identity. ${ }^{341}$ HUD ultimately declined to create a database to track cases related to the LGBTQ+ community citing concerns about the sensitive nature of data on sexual orientation and gender identity. ${ }^{342}$ HUD said that it would take time to study the best way to capture data to address the concerns from the commentary. ${ }^{343}$ However, no such database or tracking data currently exists. ${ }^{344}$ The CFPB may nevertheless be able to work with HUD to capitalize on HUD's experience, analysis, or feedback related to sexual orientation and gender identity data points. ${ }^{345}$

Implementation of new mandatory data points under HMDA or Section 1071 could necessitate new rules and regulations on documentation or data storage requirements due to the sensitive nature of information about sexual orientation and gender identity. ${ }^{346}$ There is a chance that the data requirements may overlap with various data protection requirements across many different laws such as the Gramm-Leach-Bliley Act (GLBA), the Electronic Communications Privacy Act (ECPA), and the Consumer Financial Protection Act (CFPA) ${ }^{347}$ This article will focus on the GLBA.

The GLBA is implemented via Regulation P and governs how financial institutions handle a consumer's nonpublic personal information. ${ }^{348}$ Institutions cannot disclose this information to nonaffiliated parties without the consumer's consent and must provide notice of their privacy policies and practices on a routine basis. ${ }^{349}$ Organizations must provide an initial notice when the customer relationship is established and an annual notice thereafter for as long as the relationship lasts. ${ }^{350}$ The notice must explain what data the institutions collect about the consumer, where the data is shared, how the information will be used,

\footnotetext{
341. See id.

342. See id.

343. See id.

344. See Equal Access to Housing in HUD Programs Regardless of Sexual Orientation or Gender Identity, 81 Fed. Reg. 64,763, 64776 (Sept. 21, 2016) [hereinafter 2016 Equal Access Rule] (codified at 24 C.F.R. pt. 5) (continuing to decline creating a database to track LGBTQ+ datapoints).

345. See 2016 Equal Access Rule, supra note 344; 2012 Equal Access Rule, supra note 182, at $5663,5669-70$ (addressing public comments on the lack of data to identify discrimination against the LBTQ+ community in housing and urging HUD to create a database to help identify discrimination against the community).

346. See id.

347. See Data Protection Law, supra note 334.

348. See Gramm-Leach-Bliley Act, 15 U.S.C. § 6801; 12 C.F.R. pt. 1016.

349. Id. at $\S \S 6802-03$.

350. See Chris BRUMMER, FinTECH LAW IN A NUTShell 486-88 (2020) (providing background information on the GLBA); CFPB Announces First No-Action Letter to Upstart Network, CONSUMER FIN. Prot. Bureau: NewSROOM (Sept. 14, 2017) [hereinafter Upstart NAL Announcement], https:// www.consumerfinance.gov/about-us/newsroom/cfpb-announces-first-no-action-letter-upstart-network/ (announcing relationship with Upstart, a tech company entering the financial industry that was not subject to regulation by other FIRREA).
} 
and how it will be protected. ${ }^{351}$ However, this barrier is often a mere formality as institutions can claim consent via consumer inaction in response to the required annual notice as many, if not most, consumers ignore physical mail sent to them. A digital solution is likely to be just as ineffective as consumers are equally unlikely to read a message with the title of "Annual Privacy Disclosure Notice" in their personal email or the institution's internal web messaging portal.

If sexual orientation and gender identity become collected data points, guidance may be needed on how to comply with GLBA with respect to those data points to avoid accidental outings. ${ }^{352}$ Members of the community will be at various points of being "out" throughout their lives, from closeted, partially out to either friends and family or at work (but not necessarily inclusive of all three), and fully out. Barring making data points on sexual orientation and gender identity categorically nonpublic personal information, difficult determinations may need to be made about the point at which being "out" is considered public information. Finally, it would be irresponsible not to mention the dangers of an undetected hack and the ripple effects. ${ }^{353}$ Regulators and institutions will need to consider the appropriate procedures and safeguards to protect AI systems (discussed in Part VI) and the underlying data in addition to any new data breach notification procedures that may be necessary, particularly with the issue of outing consumers. ${ }^{354}$

\section{MOVING TO THE FUTURE: FAIR LENDING AND FINTECH'S USE OF MACHINE LEARNING AIS}

Since the current legal framework leaves the LGBTQ+ community in a gray area, the community may not always have an established remedy for discrimination in financial services. ${ }^{355}$ Without concrete remedies to address this discrimination, the status quo of the current regime will continue, and discrimination could increase as the use of AI with machine learning algorithms in the financial industry expands. ${ }^{356}$

\footnotetext{
351. See BRUMMER, supra note 350; see also Upstart NAL Announcement, supra note 350

352. See supra text accompanying notes 334-345.

353. See Danielle Keats Citron \& Frank Pasquale, The Scored Society: Due Process for Automated Predictions, 89 WASH. L. REv. 1, 18 (2014) [hereinafter AI Due Process] (discussing impact of AI decisions on all monetary aspects of society); Frank Pasquale, Data-Informed Duties in AI Development, 119 Colum. L. REv. 1917, 1932-33 (2019) [hereinafter AI Data Duties] (stating the danger from a hacking of the data or AI coding and asserting that insuring integrity of the data and AI code is necessary for preventing the resulting ripple effects of compromised data or AI coding); FinReglab, Market and Policy Challenges are Slowing USe of Cash-Flow Data in U.S. CREDIT UNDERWRITING 1 (2020), https://finreglab.org/wp-content/uploads/2020/02/FinRegLab _Press-Release_02-26-2020_Cash-Flow-Data-Policy-Report.pdf (describing data risks and security concerns in fintech).

354. See AI Due Process, supra note 353, at 18 (stating need for procedural safeguards in AI).

355. See Holder Memo, supra note 13; Sessions Memo, supra note 13.

356. See Allen Business as Usual supra note 251; Hilary J. Allen, Driverless Finance, 10 HARV. Bus. L. REV. 157, 169 (2020) [hereinafter Allen Driverless Finance] (discussing business efficiencies
} 


\section{A. Machine Learning AI's Role in Fintech and the Potential Liabilities}

The term AI encompasses any computer-based system that can mimic human behavior by taking the associated inputs and performing the tasks that normally require human intelligence to create the associated output. ${ }^{357}$ From a pop-culture standpoint, one of the most popular representations that people associate with the concept of AI is Skynet from the Terminator movie franchise. ${ }^{358}$ However, that association is far from the truth as today's AIs are not independently intelligent thinking machines. ${ }^{359}$ Many successful AI systems are not fully autonomous but rather involve hybrids of computer and human decision-making (human-in-theloop system). ${ }^{360}$

There are two main categories of AI based on how they operate. The first category is where the field of AI began and involves knowledge representation and logic rules, in which explicit facts and rules about some activity are programmed into software, harnessing the knowledge of domain experts about how some system or activity operates. ${ }^{361}$ In short, a human can follow the AI's actions through the "decision-making process" and know the exact reasons for the AI's output. In the financial sector, financial institutions use this type of AI to create efficiencies, such as screening and rating applications for financial services. ${ }^{362}$

The second category, which is the type of AI that this article is concerned about, involves the system analyzing data for patterns previously encountered and makes predictions, better known as "machine learning." ${ }^{363}$ Machine learning has

of AI algorithms); ROBERT BARTLETT ET AL., CONSUMER-LENDING DisCRIMINATION IN THE FINTECH ERA 4 (2019), https://faculty.haas.berkeley.edu/morse/research/papers/discrim.pdf (claiming fintech AIs discriminate against minorities); Chris DeBrusk, The Risk of Machine-Learning Bias (and How to Prevent It", MIT SLOAN MGMT. REVIEW (Mar. 26, 2018), https:// sloanreview.mit.edu/article/the-risk-of-machine-learning-bias-and-how-to-prevent-it/ (stating risk of building bias in $\mathrm{AI}$ algorithms).

357. Artificial Intelligence, MERRIAM-WEBSTER, https://www.merriam-webster.com/dictionary/ artificial\%20intelligence (Sept. 29, 2021).

358. The Terminator (Paramount Pictures 1984).

359. Harry Surden, Artificial Intelligence and Law: An Overview, 35 GA. ST. U. L. REV. 1305, 1308-09 (2019).

360. Id. at 1320 .

361. Id. at 1319 and 1327.

362. Allen Driverless Finance, supra note 356; Allen Business as Usual supra note 251, at 86364 (2015) (stating criminal law and private litigation not effective to address financial industry's negative behavior); Anya Prince \& Daniel Schwartz, Proxy Discrimination in the Age of Artificial Intelligence and Big Data, 105 IowA L. REv. 1257, 1267, 1273-74, 1283 (2019) [hereinafter AI Proxy Discrimination] (defining proxy discrimination as when discrimination against a protected class happens based on factors that are not protected statuses, and providing AI's history, evolution, general business impact, and risks).

363. See AI Proxy Discrimination, supra note 362 at 1317; Dr. Iria Giuffrida, Liability for AI Decision-Making, 88 FORDHAM L. REV. 439, 445 (2019) (describing two types of AI systems, the first being one where humans based their decision on the system's output and the other being an "out of the loop" system because the system is fully autonomous and there is no human connection to the decision); Princeton University Center for Information Technology Policy, CITP Launch Initiative on 
two general subgroups based on the level of human involvement in creating the algorithm and validating its output. ${ }^{364}$ For the first subgroup, humans have a high level of involvement with the algorithm's creation and also validate the AI's output for quality control. ${ }^{365}$ An example is having humans select only the images with faces and then comparing the data from the humans to the output of the AI. Simple machine learning falls within this first subgroup because it utilizes known algorithms to create the output, and, like the first category, a human with subject matter expertise would be able to know how the algorithm arrived at the output. A simple machine learning AI for facial detection would comprise multiple algorithms (e.g., detection of edges, small features, and large features) that are combined to run in a specific order to create the final output to determine if there is a face in the picture.

The second subgroup is called "deep learning" which relies on neural nets, sometimes referred to as a "black box algorithm" because a human is not always able to have full insight into how the AI created its output. ${ }^{366} \mathrm{Here}$, the neural net learns by being fed a control set of data (using the previous facial detection example, the control set would be pictures of faces that the engineer selected), and the algorithm would generate parameters for detecting faces in other pictures based on the connections made through the control data. ${ }^{367}$ As a result, the neural net AI process is encompassed within one singular facial detection algorithm. ${ }^{368}$ While the engineer's involvement with selecting the control data technically involves a human, the engineer's actions are not incorporated into the neural network. Thus, even with human involvement, it is almost impossible to understand how a neural net AI works as the AI's process is not transparent or easy to audit, cannot be monitored, and creates an opportunity for discrimination or unwanted manipulation to happen. ${ }^{369}$

In the beginning, the financial industry's neural net AIs learned from datasets of human decisions to develop the AIs' decision-making rules. ${ }^{370}$ Now, these AIs can find new and better correlations between the traditional data points for a

AI and Policy: Ed Felten, YouTuBE (Dec. 12, 2017), https://youtu.be/JRDnL6Yssbg (providing background on AI); CGP Grey, How Machines Learn, YouTUBE (Dec. 18, 2017) https:// www.youtube.com/watch? $\mathrm{v}=\mathrm{R} 9 \mathrm{OHn} 5 \mathrm{ZF} 4 \mathrm{Uo}$ (illustrating how AIs are built and tested).

364. See sources cited supra note 363.

365. See sources cited supra note 363.

366. See sources cited supra note 363; Email from Susanna Mostaghim, Cloud Solutions Architect - Advanced Analytics and AI at Microsoft Azure, to Cyrus Mostaghim, Author (June, 18, 2021, 3:38 PM ET) (on file with author) [hereinafter S. Mostaghim email].

367. S. Mostaghim email, supra note 366 (discussing deep learning and engineer's actions).

368. See S. Mostaghim email, supra note 366 (discussing deep learning and engineer's actions).

369. Jack M. Balkin, 2016 Sidley Austin Distinguished Lecture on Big Data Law and Policy: The Three Laws of Robotics in the Age of Big Data, 78 OHIO ST. L.J. 1217, 1239 (2017) (expressing concerns about AI and its impact on society); CGP Grey, supra note 363 (illustrating how AIs are built and tested). See Allen Business as Usual supra note 251; Allen Driverless Finance, supra note 356; AI Proxy Discrimination, supra note 362.

370. See Allen Driverless Finance, supra note 356 at 161-62; BARTLETT ET AL., supra note 356 at 7; DeBrusk, supra note 356. 
decision. ${ }^{371}$ Similar to how Facebook creates a user insight page, these algorithms are starting to use data from external sources like online transactions, internet history, and social network activity to develop predictions with the same transparency concerns. ${ }^{372}$ The impact of AI on the financial industry is not limited to deposit-taking banks and mortgages. ${ }^{373}$ Financial institutions that are not banks can use AI to decide what credit cards to offer, the individuals that qualify for the credit card, and the interest rate, transaction fees for financial services like trading stocks, and interest on loans issued by banks or non-banks like Quicken Rocket Mortgage.

Financial institutions should be concerned about potential future liability related to AI decisions because if an institution's algorithm violates any of the fair lending statutes, the institution may be held legally responsible and required to pay damages and penalties. The institution could be held responsible because, ultimately, the decision becomes the institution's when it adopts the AI's output. ${ }^{374}$ The level of liability would also hinge on whether the institution automatically adopted the AI system's decision or if a human reviewed the output and decided that it was acceptable. ${ }^{375}$ While there is uncertainty about liability in this context, institutions should monitor and adjust as case law and regulations develop. ${ }^{376}$ Financial institutions will face more risk of responsibility for liability than just the violation of a financial statute. A financial institution could also be liable for damages associated with an individual consumer's common-law tort claim, a class-action claim, or even a product liability tort claim. ${ }^{377}$ Additionally, these liabilities could increase if the AI's decisions appear to discriminate against a protected status. ${ }^{378}$

371. See Student Borrower Protection Ctr., Educational Redlining, 15-19 (Feb. 2020), https://protectborrowers.org/wp-content/uploads/2020/02/Education-Redlining-Report.pdf; Allen Driverless Finance, supra note 356; Balkin, supra note 369; AI Proxy Discrimination, supra note 362.

372. See AI Proxy Discrimination, supra note 362.

373. See AI Data Duties, supra note 353, at 1925 (discussing development and advancement of AI algorithms).

374. See Giuffrida, supra note 363; Lyle Morgan, AI Certification Initiatives Could Prove Very Useful to Legal Industry, Experts Say, ABA JouRnAL (Mar. 23, 2021), https://www.abajournal.com/web/article/aicertification-initiatives-could-prove-very-useful-to-legal-industry-experts-say (discussing the various parties that have some amount of responsibility for the liability when "AI systems produce problematic results").

375. See sources cited supra note 374.

376. See Giuffrida, supra note 363, at 445-47 (examining an institution's liability risk for AI decisions).

377. See id.; AI Data Duties, supra note 353, at 1925-26 (discussing development and advancement of AI algorithms); Cyrus Mostaghim, "The Danger of Proxy Discrimination in FinTech and the Need for Regulatory Sandboxes", AM. U. Bus. L. ReV.: THE BLR Buzz Blog (Apr. 1, 2020) [hereinafter Mostaghim Proxy Discrimination], http://www.aublr.org/2020/04/the-danger-of-proxydiscrimination-in-fintech-and-the-need-for-regulatory-sandboxes/ (asserting the danger of AI proxy discrimination).

378. Mostaghim Proxy Discrimination, supra note 377. 


\section{B. The Risk of AI Discrimination}

Using datasets of human decisions to create AIs is problematic because the AI is only as good as the data used to teach the algorithm. ${ }^{379}$ Thus, there is a chance that datasets may include examples of discriminatory lending against the LGBTQ+ community that gets built into the fintech models, resulting in new discriminatory lending actions; the need to fix things now is even more critical. ${ }^{380}$ Even worse, the data could cause discrimination or be used to hide discrimination against the LGBTQ+ community or any other protected class in a way that would be harder to detect since a regulator cannot audit the algorithm's programming. ${ }^{381}$ Attention must also be directed at the individuals programming the algorithms to ensure the engineer's unconscious or active biases do not affect the programming or any step of the process (data collection, data cleaning, data transformation, variable/feature selection, model building, and review). ${ }^{382}$ Finally, another concern related to discrimination in AI is that AIs may make inappropriate decisions based on correlations in the data, i.e. when Facebook's AI moderator removed legitimate posts about the Coronavirus. ${ }^{383}$

Decisions that indirectly impact a protected status in a negative manner (because the decision was not based on a protected status, but was based on factors that were a proxy for the status) are a type of discrimination known as proxy discrimination. ${ }^{384}$ Already, there are allegations of AI-driven proxy discrimination against minorities in financial services. ${ }^{385}$ One allegation came from the Student Borrower Protection Center in a report about a fintech company, Upstart, claiming that the AI engaged in discrimination through the use of nontraditional lending data. ${ }^{386}$

Big tech companies with massive amounts of consumer data (like Facebook and Google) are exploring the provision of financial services. ${ }^{387}$ That data includes all kinds of consumer information that the financial industry does not

379. See DeBrusk, supra note 356.

380. Balkin, supra note 371.

381. See Balkin, supra note 371; AI Due Process, supra note 353, at 10 (stating inability to audit AI algorithms); AI Data Duties, supra note 353, at 1918 (postulating danger of using AI to deflect liability); Mostaghim LGBTQ+ Discrimination, supra note 261.

382. See AI Due Process, supra note 353, at 13-14 (postulating risk of engineer's unconscious bias impacting AI code and datasets).

383. Paresh Dave, Social Media Giants Warn of AI Moderation Errors as Coronavirus Empties Offices, REUTERS (Mar. 16, 2020), https://www.reuters.com/article/us-health-coronavirus-googleidUSKBN2133BM.

384. AI Proxy Discrimination, supra note 362, at 1268, 1285 (identifying proxy discrimination).

385. See Mostaghim Proxy Discrimination, supra note 377.

386. See Upstart Report, supra note 235.

387. See Ryan Brown, Big Tech Will Push Deeper into Finance This Year-But Avoid the 'Headache' of Being a Bank, CNBC (Jan. 3, 2020), https://www.cnbc.com/2020/01/03/big-tech-willpush-into-finance-in-2020-while-avoiding-bank-regulation.html (discussing Facebook, Google, and Apple entering the finance industry). 
currently utilize in making financial decisions: the use of these new kinds of data would magnify the risk of direct or proxy discrimination. ${ }^{388}$ The use of such varied and detailed forms of data also magnifies concerns about the difficulties in comprehending an AI's decisions and identification of what was the contributing factor(s) for a discriminatory action. ${ }^{389}$ However, the concern is not necessarily unique to big tech because as long as financial institutions comply with the applicable data privacy laws, institutions may be able to purchase these new kinds of data about their customers. ${ }^{390}$

The data used in fintech's AIs blend to create another issue related to data privacy and outing: this type of AI data mining may allow an institution to learn or infer sexual orientation or gender identity outside of a self-identification, which could result in proxy-discrimination. ${ }^{391}$ Similar to how the community uses "gaydar" to identify other members while out in public, data about an individual's preferences, likes, frequently patronized businesses, and other similar information could allow an AI to infer sexual orientation or gender identity. ${ }^{392}$ In other words, the techniques for the in-person observation of social cues, actions, and other visual and sound data to make an in-person assessment can also be applied to the digital world. ${ }^{393}$ Researchers are already trying to create AIs that can determine a person's sexual orientation. ${ }^{394}$ Digital data of interest might include the target individual's common Facebook friends, their liked Facebook pages, the hashtags they used for Instagram posts, and even the accounts the individual follows on Instagram. The various online quizzes online that claim to be able to guess an individual's sexual orientation are examples of simple "gaydar

388. Dan Murphy, Big Tech's Invasion of Banking, MiLKEN INST. ReV. (Apr. 26, 2019), https://www.milkenreview.org/articles/big-techs-invasion-of-banking (asserting big tech can access better data than banks); see Brown, supra note 387; see supra notes 348-352 and accompanying text.

389. See supra text accompanying notes 383-385; Balkin, supra note 371; AI Due Process, supra note 353, at 10 (stating inability to audit AI coding); AI Data Duties, supra note 353, at 1918 (postulating danger of using AI to deflect liability); Mostaghim LGBTQ+ Discrimination, supra note 261.

390. See Tom Groenfeldt, PNC Launches a Fintech Startup Inside the Bank, ForBES (Aug. 29, 2019), https://www.forbes.com/sites/tomgroenfeldt/2019/08/29/pnc-launches-a-fintech-startup-insidethe-bank/ (highlighting PNC's creation of a fintech subsidiary that does not use any data PNC collects, only anonymized data that is purchased); see supra Part V Section c.

391. See AI Proxy Discrimination, supra note 362, at 1274-75, 1291 (providing AI's history and evolution, general business impact, risks, and applicability to financial services); Mostaghim LGBTQ+ Discrimination, supra note 381.

392. See Justin Lehmiller, The Science of "Gaydar": How Well Can We Detect Other People's Sexual Orientation?, IND. UNIV. KINSEY INST., https://kinseyinstitute.org/news-events/news/201712-18-gaydar.php (explaining gaydar) (last visited July 1, 2021); see supra notes 381-83.

393. See id.; Elija Marc Cassidy, The Convergence of Niche and Mainstream Social Networking Services in Gay Men's Digital Culture: How Generation Y Uses Facebook to Extend and Enhance the Gaydar Experience (2014), https://spir.aoir.org/ojs/index.php/spir/article/view/9027/7122 (discussing how gay men use social media to confirm another individual's sexual orientation).

394. James Vincent, The Invention of AI 'Gaydar' Could be the Start of Something Much Worse, Vox (Sept. 21, 2017), https://www.theverge.com/2017/9/21/16332760/ai-sexuality-gaydarphoto-physiognomy. 
AIs." ${ }^{395}$ Imagine the correlations, correct and incorrect, that fintech's AIs could make with the massive amount of consumer data in their databases, particularly if big tech becomes part of the financial industry.

If discrimination is not properly addressed now, it will be built into all computer-based decision-making. ${ }^{396}$ The cost to correct the discriminatory algorithms will increase exponentially down the road versus getting it right while we are still in the infancy of fintech. ${ }^{397}$ This cost may not be limited to corrective action as there is always a risk of legal liability for past actions, particularly if the FTC's guidance on AI discrimination and UDAP remains, if CFPB issues similar guidance for UDAAP, or if both agencies issue more formal regulations related to the matter. ${ }^{398}$

\section{CONCLUSION}

Without action at the federal level that creates more concrete protections for the LGBTQ+ community, the community will remain vulnerable to discrimination in access to financial services. This article has demonstrated that multiple paths can be taken to create more concrete protections, either individually or in a complementary manner. In particular, the CFPB should seriously consider the collection of data points on sexual orientation and gender identity for HMDA and the section 1071 rulemaking for small-business data. This data collection must be done in a way that balances the policy concerns unique to the LGBTQ+ community, though. A requirement to collect sexual orientation and gender identity data will likely cause some uneasiness for individuals who are not out of the closet, and so this data must be handled securely and sensitively. However, the collection of these data points will enable regulators and the public to be able to identify lender actions that indicate a potential discriminatory impact on the LGBTQ+ community.

More concrete protections should be pursued quickly to prevent discrimination from being incorporated in fintech's AI algorithms. The fintech sector is already using previous credit decisions to train fintech's AI algorithms, and those decisions may be discriminatory against the LGBTQ+ community. This discrimination is hard to remove from an algorithm after the fact.

Because fintech's AI systems are growing more advanced and sophisticated each day and becoming more embedded in the foundation of our financial system, the cost of correction will increase exponentially the longer it takes to start remediation. This cost will not fall just on the financial institutions but will be passed on to consumers. Thus, almost every consumer will feel the impact in some form. The timely creation of more concrete protections for the LGBTQ+

395. GoOGLE, https://google.com (search for "quizzes to guess if gay") (last visited May 2, 2021).

396. See AI Due Process, supra note 353, at 18 (stating need for procedural safeguards in AI).

397. See id.

398. See supra notes $235-36,248$ and accompanying text. 
community will mitigate the cost of the associated ripple effects on financial institutions that ultimately will be passed on to consumers. 
